\title{
O CATARISMO E A CRUZADA CONTRA OS ALBIGENSES $\left({ }^{*}\right)$.
}

\section{INTRODUÇÃO}

Nos fins do século XI, em conseqüência da reabertura do comércio com o Oriente, passou a Europa Ocidental por profundas transformaçōes de ordem econômica que, refletindo-se sôbre a estrutura político-social do mundo medieval, provocaram a desagregação do regime feudal.

Abre-se, pois, com o século XI, uma éra de desequilíbrio e perturbações que caracterizam os períodos de transição. Mudam-se os conceitos e os padrões dos valores morais.

Estas épocas, em geral, sugerem conđições propícias ao florescimento de idéias novas que são o reflexo das novas condições sociais ou políticas oriundas das transformações econômicas. No tocante à vida religiosa ou espiritual, êstes períodos de transição, de busca de novos valores espirituais, criam clima favorável ao florescimento de heresias ou de doutrinas novas.

Através do contacto comercial restabelecido entre o Ocidente e o Oriente no século XI, processou-se, na Europa Ocidental, como na Antigüidade, um influxo de heresias orientalistas; encontrando um ambiente favorável, estas heresias disseminaram-se ràpidamente ao longo das rotas comerciais da Alemanha Renana, na Flandres, no Norte da França, na Champagne e no Languedoc.

Há uma série de razões que justificam a franca receptividade à pregação da heresia.

O esplendor da prosperidade econômica havia alcançado o clero; espiritualmente enfraquecido pelo gôzo dos bens materiais, faltava-lhe fôrça moral para combater as heresias. Assim, pois, com pretextos e excusas, adiava-se a ação contra elas.

Jacques de Vitry, bispo de São João d'Acre e mais tarde cardeal de Curie, quando esteve em 1216 em visita à côrte pontifical em Perusa, assim escreveu, após a morte de Inocêncio III: - "Encontrei coisas aqui, que não me convêm. Estamos de tal maneira ocupados com coisas temporais e mundanas, com reis e com reinos, com processos e queixas, que mui pouco se permite falar de coisas espirituais". Um pouco mais adiante fala também de "religião

(*). - Trabalho epresentado para obtençäo de nota de aproveitamento no Curso de Especialização em História da Civilização Medieval (E. Simóes de Pauta). 
completamente abatida e quase morta" e da aproximação do AntiCristo (1).

Difícil era, pois, combater as heresias, quando nos grandes centros urbanos freqüentemente criticava-se os brilhantes representantes da Igreja, cuja vida parecia bem distanta do modêlo cristão.

Por circunstâncias econômico-sociais particulares à burguesia e ao proletariado urbano e rural, foi que, entre estas classes sociais, os pregadores heréticcs recrutaram o maior número de prosélitos.

Com a intersificação, a burguesia adquiriu considerável importância política. Na época da expansão do movimento comunal, o clero, em geral, manteve-se hostil à liberdade das comunas, mas não tinha fôrça moral para deter as reivindicações dos burgueses. Uma das formas de reação da burguesia contra o clero foi a adesão à heresia.

Mas foi dentro da grande massa do proletariado urbano e rural que os pregadores recrutaram o maior número de adeptos. Com tendências ao misticismo, às superstições, em virtude de sua condição econômica e do baixo nivel de seus conhecimentos, abandonada dos socortos espirituais da Igreja, aderiu à pregação da heresia, à pobreza real ou eparente dos pregadores, às promessas de uma doutrina que os desligaria da sujeição em que viviam. Desvenda-se a possibilidade de um mundo melhor; era impossível que não os atraisse esta espécie de socialismo pregada pelos "perfeitos" em busca de prosélitos. Aderem por que é a oportunidade para a libertação da tutela feudal, leiga ou eclesiástica, por que prega a abolição dos juramentos, dos privilégics feudais, imposto e taxas (2).

E' por isso que, no proletariado urbano e rural, as heresias dêste tipo, encontraram o maior número de aderentes.

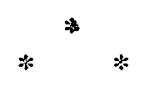

\section{ORIGENS}

O catarismo encontrou, pois, um ambiente excelente para o seu desenvolvimento. Um período de fraqueza religiosa e moral tinha necessidade de uma forte reação espiritual e o catarismo representou, realmente, êste movimento contrário ao estado da Igreja dominante e da sociedade constituida.

E' possível que o catarismo resulte de uma fusão ocorrida no Oriente, das antigas seitas dualísticas com o judaismo e o cristianismo, assim como o mitraísmo teria surgido do contacto entre a antiga religião persa e o budismo (3).

\footnotetext{
(1). - Encyclopaedia of Religion and Ethics - vol. I - pág. 280.

(2). - Gustave Schnürer - "L'Êglise et la civilisation au Moyen Âge" - vol. II

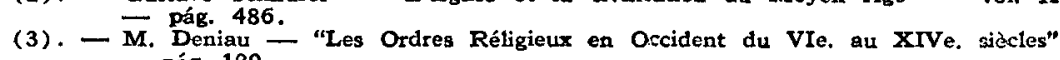


Tem suas raízes remotas nos movimentos dualísticos de paulicianos, messalianos, sabelianos, euchitas e outras heresias derivadas do gnosticismo. Entretanto, de tôdas estas heresias, tem mais afinidades com a heresia dos bogomilos, paulicianistas que se fixaram na Bulgária. Daí o nome com que, geralmente, os bogomilos são conhecidos: bulgari ou bougres, corruptela dêste nome e que passou a designar na França, todos os herejes. Literalmente, na língua local, bogomilos quer dizer "amigos de Deus".

Como os gnósticos e maniqueus, elaboraram uma cosmologis dualística; à doutrina dos sabélios, assemelha-se a sua doutrina sôbre a Trindade. Como os docetistas crêm que o trabalho da "aparência de Cristo" foi vencer a fôrça dos espíritos decaídos que dominavam aqui. Como os bogomilos e outras heresias maniqueistas, substituiram o sacramento do batismo por uma cerimônia iniciatória que consistia na invocação do Santo Espírito, colocando sôbre a cabeça do candidato o Evangelho de São João e repetindo a oração do "Pai Nosso". Rejeitavam a Ceia do Senhor, considerando que o pão da comunhão é o último discurso de Cristo no Evangelho. Como os maniqueus rejeitavam o uso da carne e o casamento. Como os paulicianos rejeitavam o uso de imagens como idolatria e consideravam como satânicas as Igrejas Grega e Romana.

O catarismo não é, pois, uma teligião nova, mas um nome novo dado a velhas doutrinas, sobrevivências, provàvelmente, do maniqueismo do Sudoeste europeu.

Parece que não há necessidade de hipóteses engenhosas para estabelecer-se a filiação do catarismo que se expandiu no SO. da Europa, com as antigas seitas orientalistas da Europa Oriental e Ásia Menor. A simples comparação da cosmogonia e da teologia destas seitas é suficente para provarmos a filiação que há entre elas.

No tempo de Diocleciano houve larga expansão das seitas dualísticas no Oriente; as maniqueus foram vigorosamente perseguidos por Diocleciano e pelos imperadores cristãos. Estas seitas tiveram larga difusão na África Romana e aí foram combatidas por Santo Agostinho (4).

Um pouco antes de Justiniano os maniqueus foram expulsos de Constantinopla e fundaram, então, uma colônia em Filipopoli. $\mathbb{E}^{\prime}$ daí, então, que se' processa a sua difusão pela Península Balcânica. Durante muitos séculos a seita esteve pràticamente desaparecida, ressurgindo apenas em um ou outro ponto. Assim, o catarismo procede, provàvelmente, da Armênia, tendo penetrado na Europa pela rota búlgara e pelas rotas comerciais difunde-se pelo Ocidente.

A seita teve grande desenvolvimento na planície lombarda, durante o período da "Querela das Investiduras", onde os seus adep-

(4). - Idem, obr. cit. - pág. 129. 
tos tomavam o nome de pataros, patarini, ou mendigos. Pregavam a completa renúncia aos bens materiais, a pobreza voluntária, a castidade. Criticavam fortemente os bispos que se imiscuiam nas lutas políticas, que viviam de barrete militar na cabeça e se esqueciam de suas ovelhas. Representavam, êstes bispos, a opressão contra as comunas que queriam libertar-se da tutela episcopal; assim, o movimento pataro, essencialmente de reação contra a venalidade do clero, teve grande importância no desenvolvimento da luta das comunas italianas do vale do Pó. O seu grande chefe foi Arnaldo de Bréscia, que teve um fim trágico. Decairam os pataros com a morte de seu chefe.

Por êste tempo o movimento cataro, porém, já havia atingido o seu ponto de eleição: o Sul da França.

Em virtude da obscuridade da história dos diferentes estados italianos no século $\mathrm{X}$ e parte do século XI, torna-se impossível estabelecer com segurança as datas e as circunstâncias em que ocorreram as migrações dos paulicianos, os quais deixaram a Bulgária e passaram para a Itália, Europa Central e Ocidental. Historiadores como Ussher, Limborch e Chandler, apontam inúmeras conexões entre os albigenses e as seitas orientalistas. Alguns autores chegam a identificar os albigenses com os paulicianos emigrantes, tomando por base as suas doutrinas que possuem entre si, inúmeros pontos de contato.

O Prof. Karl Muller (5) é de opinião que os dogmas dos albigenses cataros resultam da fusão de doutrinas paulicianas com as doutrinas dos euchitas e que essa fusão processou-se na Trácia (Bulgária). Como emigrantes, transportaram esta doutrina que carregou-se, então, de tendências gnóstico-dualísticas .

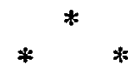

\section{TRAÇOS DA DOUTRINA}

E' muito difícil o estudo das doutrinas cataristas, uma vez que os textos cataros autênticos são raríssimos. Existe na Biblioteca de Lião um ritual cataro; em 1939 foi encontrado em Florença, por um padre dominicano, o Pe. Dondaine, um texto cataro autêntico, o De Duobus Principiis. O que se conhece sôbre êles é o que dizem os seus comentadores contemporâneos e posteriores, os autos do Tribunal da Inquisição, sempre suspeitos pelo excessivo fanatismo.

O catarismo oriental puro, parece ter sido modificado pelas escolas ocidentais. A principal diferença entre êles, consiste no seguinte: uma parte, entre os cataristas, firma-se num absoluto dua-

(5). - Encyclopaedia of Religion and Ethics - páq. 278. 
lismo, estabelecendo a existência de dois princípios, um oposto ao outro, e duas criações correspondentes aos dois princípios; os demais admitem, entretanto, a existência de um relativo dualismo; para êstes o mal deriva de um espírito expulso do Céu por Deus e que foi o autor de uma revolução no Universo. Neste grupo de cataristas podemos perceber uma íntima relação com os bogomilos e sua derivação, quase certa, desta seita. Esta derivação é confirmada pelo Evangelho apócrifo de São João, o qual foi trazido para a Europa Ocidental pelo seu bispo, Nazário da Bulgária.

Entretanto, por outro lado, podemos traçar com muita propriedade, inúmeros traços de afinidade entre as diferentes seitas, dentro do catarismo.

Podemos, como os escritores contemporâneos, considerar o maniqueismo como a fonte comum a tôda elas, da qual derivou a sua tendência ao dualismo. As marcas do maniqueismo são indiscutíveis. Sua doutrina concernente à criação, à origem do homem, a Cristo, é indiscutivelmente maniqueista, e principalmente paulicianista, ou de outras seitas derivadas do gnosticismo. Dos paulicianistas distinguem-se pelos fatos de aquêles não admitirem a oposição entre "esotéricos" e "exotéricos", e de existir entre êstes últimos.

Os cataros, em geral, supõem a existência de dois princípios: $\left.1 .^{\circ}\right)$ o princípio do Bem, que é Deus, fonte do mundo imperecível, relativo à sua própria qualidade eternal; $2 .^{\circ}$ ) para êles tôda a existência perecível é nula, mentirosa e só pode ser atribuida ao princípio do mal.

Em defesa do seu dualismo apelam para muitas passagens do Velho e do Novo Testamento; tudo aquilo que concerne à oposição entre a carne e o espírito, mundo e Deus, interpretam neste sentido. Insistem muito na passagem de João, 8:44, na qual o Demônio é tido como mentiroso desde o princípio e incapaz de praticar a Verdade e a Bondade.

"Vós sois filhos do Diabo e tendes vontade de cumprir os desejos de vosso pai. Ele era homicida desde o principio e não permaneceu na Verdade, porque não há nele a verdade. Quando êle diz uma mentira, fala do que lhe é porque é mentiroso, é o pai da mentira".

Como seus oponentes, tomam Aristóteles como irrefutável autoridade para favorecê-los.

Para cada alma corresponde um espírito que é o orgão que a determina e guia; a cada uma delas subordina-se um corpo celestial, inteiramente dependente, como se fôsse o mais alto espírito do indivíduo. Estes espíritos assemelham-se aos anjos. Podemos reconhecer aqui a Syzygya da doutrina gnóstica.

Pela sua apostasia (rebelião de anjos, comandada por Satã), estas almas celestiais abandonaram a harmoniosa conexão com o mundo celestial. Expulso Satã do Céu, êle foi separado dos espiritos que a êste pertenciam e dos corpos celestiais que lá permaneceram. Satã, então, tratou de atar ao mundo corporal as almas 
expulsas do Céu, as quais agora reaparecem sob o véu do corpo humano. Isso tem, provàvelmente conexão com a sua doutrina da metempsicose. Nesta base combatem o creacionismo. Argumentos do Livro do Deuteronômio servem para apoiar a doutrina da metempsicose (Deut., 18:1).

Dentre as almas celestiais distinguem-se diferentes classes, de acôrdo com as diferentes classes de príncipes do Céu. Para explicar essa doutrina, conciliam Mateus, 25:24 com João, 10:16.

\section{-}

Mateus, 25:24 - "Senhor, eu soube que és um homem severo; ceifas onde não semeastes e recolhes onde não joeiraste" (Parábola dos talentos).

Joâo, 10:16 - "Tenho também outras ovelhas que não são dêste aprisco; estas também é necessário que as traga".

E' difícil compreendermos como conciliavam os cataros, estas duas passagens do Novo Testamento, como argumentos para provar a existência de diferentes galardões no reino dos céus.

Afirmam, entretanto, que foi especialmente para salvar as grandes raças de almas, "as ovelhas perdidas da Casa de Israel", que Cristo veio ao mundo; mas veio também para salvar as "outras ovelhas" que não eram do aprisco, outros príncipes do Céu, que são os pagãos. Estes cataristas negam, pois, a liberdade da vontade; produzem, então, argumentos contra o livre-arbítrio, que determina a livre escolha entre o Bem e o $\mathrm{Mal}$, o que não se pode admitir para o caso de Deus que, sendo bom, só pode escolher o Bem. Apelavam para o texto do Capítulo IX da Epístola de São Paulo aos Romanos, empregada por outros também como prova da doutrina da predestinação incondicional. Isto, porém, não está de acôrdo com a sua doutrina sôbre a queda, sôbre o arrependimento e sôbre o processo de purificação. Atribuiam, provàvelmente, a existência indubitável do livre-arbítrio ao domínio do mal sôbre a terra.

A Cristologia catarista é bastante interessante; para êles "Cristo não era Deus e muito menos um homem, mas o mais alto espírito depois de Deus, um anjo adotado por Deus, que havia tomado aparência de homem, diferindo Dêle em essência e a Ele subordinado"; aceitavam também a existência de uma subordinação entre o Espírito Santo e o Filho de Deus.

Para apoiar êstes dogmas recorrem a passagens do Novo e do Velho Testamentos e especialmente Provérbios, 8:22.

"O Senhor me possuiu no principio de seus caminhos e antes de suas obras mais antigas".

No entanto, fazendołse a exegese do contexto, observa-se que é a sabedoria que o Senhor possuiu desde o principio. Interpretando-se esta passagem no sentido literal, como o fazem os cataros, Cristo seria mera criatura, pois que são, indubitàvelmente, 
a favor da doutrina da emanação. De Deus Pai, emanou o Fitho, que não é igual a Ele. O Filho, unido ao Pai pelo Corpo e pelo Espírito nesse mundo celestial, desceu com a Anunciação do Anjo em Maria. Os cataros e mesmo os maniqueus, admitiam, entretanto, que o corpo celestial de Cristo era, por ato especial do poder de Deus, modificado, apenas, para assemelhar-se aos corpos materiais para, assim, ser percebido pelos sentidos. O corpo "material' de Cristo, seria, pois, mera aparência.

Os milagres de Cristo, devem ser entendidos no sentido espiritual, símbolos dos milagres espirituais que fazia. A prova dêste dogma são as palavras de São Paulo: "A letra mata, o espírito vivifica". No entanto, o apóstolo refere-se aqui à lei, interpretada e praticada à risca; a lei, assim posta em prática, nem sempre é fonte de bem; às vêzes, pode ser motivo de pecado; à prática da lei, o que importa é o espírito com que foi praticado. Sem o espírito, a lei é morta; sem boa intenção as ações não têm valor.

Para os cataros, Cristo despertou Lázaro de uma morte de pecado. A alma putrefata em virtude do pecado é purificada pela fé que habita no coração de Lázaro.

A negação dos milagres de Jesús condiz com a sua doutrina dualística, à oposição entre os dois princípios sobrenaturais. Nem poderia tomar como verdadeiros os milagres materiais de Cristo, porque o mundo sensível é um trabalho do princípio do mal. Cristo, espirito perfeito, não podia atenđer às contingências da carne.

A tendência ultra-supernaturalística dos cataros chega a considerar Maria, um anjo errante e João, apóstolo particularmente reverenciado por êles, como um anjo também .

O exagêro destas tendências levou os cataros do Sul da França a considerarem o Cristo corporal, nascido na Belém visível e crucificado em Jerusalém, como o produto do princípio do mal e não hesitavam em blasfemá-lo.

O Cristo do princípio do bem, reconheciam-no sòmente como um ser ideal que não tem fome nem sêde, não tem corpo real e existe no mundo apenas espiritualmente na pessoa do Apóstolo São Paulo, que exaltou a figura do Cristo histórico; sua doutrina é a coordenação do genuino cristianismo espiritual; é, pois, a aparência do Cristo ideal que nele toma figura.

Uma parte dos cataristas, denominada Ordibarii, pensa que a Trindade começou a existir com o nascimento de Cristo. O homem, Jesús, tornou-se filho de Deus pela recepção da palavra que a Ele foi dada; era filho de Maria, corporal, mas não espiritualmente.

A parte espiritual do ser humano constituida de espírito e alma separou-se em duas porções, em virtude da apostasia. Para êstes espíritos viria o "Paráclito", prometido por Cristo, o "Consolador", o qual desceria sôbre os fiéis pelo batismo espiritual que êles chamavam Consoỉamentum. Esperavam também por um tríplice julgamento que consistiria: 1) na expulsão das almas apóstatas; 
2) isto se daria com a nova vinda de Cristo; 3) seriam, então, elevados para os altos céus por Ele preparados, os espíritos dos remidos. Estaria, assim, tudo consumado; as almas reunir-se-iam aos seus espiritos para a vida celestial. Este era o seu conceito sôbre a ressurreição.

Um segundo grupo de cataros não aceitava a eternidade do mal; todo o mal derivaria da apostasia dos altos espíritos. Também admitiam que Deus, do caos criou o princípio de tôda a matéria e que de Satã procede a forma dada a elas. Mas Satã apoderou-se de Adão e o aprisionou num corpo terreal.

O mundo sideral, que deriva da forma dada à matéria criada. por Deus, por Satã, é, portanto, o reino do mal. Seguindo uma antiga noção, reconheciam no Sol, o macho e na Lua, a fêmea. Com o consentimento de Deus, Satã elaborou as formas do mundo material em seis dias de liberdade que Ele lhe concedeu; Satã havia. prometido produzir um número de homens correspondente apenas. ao número de anjos apóstatas. Mas Satã inventou a relação sexual que poria o espírito na inteira dependência dos sentidos e multiplicaria indefinidamente o número de prisões corporais para as. almas celestiais. Das relações dentre Satã e Eva, que era um anjo decaído, nasceu Caim. O pecado de Adão, ao comer o fruto proibido, foi o contacto carnal com Eva; desta união nasceu Abel. Da. alma celestial de Adão derivam as outras almas que trazem em si, a essência do pecado.

De acôrdo com esta doutrina, Satã é o Deus do Velho Testamento, Deus guerreiro, sanguinário, vingativo. O verdadeiro Deus, Deus bom e compassivo, interferiu apenas para a preservação da raça, salvando Noé. Moisés e os Profetas, de acôrdo com as doutrinas cataristas, são servos de Satanás. Há, pois, uma oposição: essencial entre o Velho e o Novo Testamento; para provar tal doutrina, apelam para a oposição entre o Sermão da Montanha e a Lei Mosaica. Para tais cataristas a Igreja Romana vivia debaixo da lei. de Moisés.

Rejeitavam também João Batista, como tendo sido enviado por Satanás para impedir o batismo de Cristo e para estabelecer uma oposição entre o batismo da água e o batismo do espírito.

Quanto à concepção da Trindade, aceitavam os mesmos dog. mas do grupo anterior, mas chamavam Deus a Cristo e ao Espírito. Santo. Como os bogomilos acham que ambos trouxeram das moradas etéreas um corpo celestial e que Maria contribuiu apenas como intermediária para a vinda de Cristo ao mundo. Maria não é verdadeiramente mãe de Jesús. Apelam para as seguintes passagens que provam esta doutrina:

João, 2:4 - "Mulher, que tenho eu contigo?"

Lucas 10:27-28 - "Enquanto assim falava, uma mulher do meio. da multidão levantou a voz e disse-lhe: Bem-aventurado o ventre que te trouxe $e$ os peitos em que foste criado. Mas êle (Jesús) respon- 
deu: Antes bem-aventurados aquêles que ouvem a palavra de Deus e a observam".

De acôrdo com outros cataristas, a comunicação do Espírito Santo se deu depois da ressurreição de Cristo.

Não aceitam a doutrina da ressurreição do corpo, porque o corpo é produto do princípio do mal. O texto de Filipenses, 3:20, refere-se à pátria celestial onde serão restaurados os espíritos em sua glória e deixados os corpos que os humilham.

Ambas as partes do catarismo opõem-se aos elementos exteriores da religião professada pela Igreja Romana. "Deus não habita em casas feitas por mãos dos homens. Não é em casas de pedras, mas no coração dos homens bons que Deus se compraz". A prece no aposento do crente tem, pois, o mesmo valor que a prece no Templo.

Isto quer dizer que entre os cataros o culto não tivesse exteriorizações. O Consolamentum, por exemplo, que é a cerimônia iniciatória da seita, tinha uma verdadeira eficácia mágica. A Igreja celestial dependia dêle, como a Igreja dominante depende dos atos sacerdotais.

Para êste grupo de cataros o batismo de João Batista é cerimônia de Satanás. Quando se objeta que Cristo recebeu tal batismo, respondem que Cristo acomodou-se ao sistema que prevalecia, para conduzir as almas ao verdadeiro batismo.

O batismo do Espírito, o verdadeiro batismo, é aquêle que designam pelo nome de Consolamentum. Evidenciando o poder e a significação dêste ato, refere-se aos apóstolos João e Pedro que foram enviados para Samária para comunicarem, pela imposição das mãos, o Espírito Santo àquêles que haviam recebido o Batismo. Quando objetou-se que havia contradição em seus princípios, pois coisas materiais, sensiveis, representavam a operação da graça divina, respondem que o Espírito Santo é comunicado não pelas mãos visíveis, mas pelas mãos invisíveis; o invisível é contido sob o visível. O Consolamentum implicava em um duplo ritual. Os iniciados eram incluidos na comunhão da seita e dos crentes ou "credentes". Quando eram recebidos no número daqueles que estavam inteiramente iniciados nos dogmas, passavam para a categoria dos "perfeitos". Nestes havia se processado o novo nascimento a que se refere Jesús em sua conversa com Nicodemos (João, 3:4-11) e se distinguiam dos demais pelo título de consolati.

O rito de imposição das mãos incluia um vasto cerimonial, assim descrito por um dos seus contemporâneos:

They assembled in a room, dark and closed in on all sides, but illuminated by a large number of lights affixed to the walls. Then the new candidate was placed in the center, where the prosiding officer of the sect laid a book (provàvelmente o Evangelho de 
São João) on his head, and gave him the imposition of hands, at the same time reciting the Lord's prayer" (6).

Apoiando-se nas palavras de Cristo: - "Meu corpo para nada aproveita, mas minhas palavras são espírito e vida" admitiam que as "palavras" (os Evangelhos) comunicavam a si mesmos, seu verdadeiro corpo.

Combatiam o sacramento da penitência, a necessidade de satisfação dos pecados cometidos depois do batismo; o consolamentưm substituia tôda outra penitência.

Para evitar o pecado, depois de recebido tal batismo espiritual submetiam-se a um rígido sistema de moral e a observância de estreitos princípios. Estes princípios e preceitos requeriam a abstinência de carne, ovos, leite e queijo porque eram produtos do intercurso sexual dos animais. Talvez só uma parte dos cataros considerava pecaminosa a morte dos animais; estavam, assim, de acôrdo com a sua doutrina da metempsicose. Permitiam, por exemplo, que se comesse peixes, pois eram considerados como sêres desprovidos de sangue e de contacto sexual ao se processar a sua multiplicação.

O casamento e tôda e qualquer relação sexual era proibida, pois tais coisas eram obras de Satã destinadas a aumentar as prisões corporais; assim, era retardado o processo de purificação pela metempsicose, porque as almas celestiais permaneceriam indefinidamente confinadas ao mundo corporal.

Às palavras de Cristo: "o que Deus juntou, não o separe o homem", davam os cataros mais dualísticos, um sentido espiritual - o casamento espiritual entre Cristo e sua Igreja. Tal forma de casamento era permitida aos homens, desde que se abstivessem de relações sexuais.

Opunham-se aos juramentos, aos derrames de sangue, ao serviço militar, à condenação à morte. As conseqüências dêstes princípios, como veremos posteriormente são de importância vital ao regime político-social vigente.

Aos esotéricos e exotéricos nesta seita, correspondiam as duas classes de "perfeitos" ou bonni homines, aos quais denominava-se "cataristas" em strictu-sensu e "credentes".

Segundo o testemunho de Rainério Sacchoni, que escreveu contra os cataros na segunda metade do século XIII, havia um grande número de credentes em tôdas as partes do munảo. Mas da classe dos "perfeitos" de ambos os sexos, havia apenas 4.000 em todo - mundo. Os "perfeitos" entre os cataros, correspondem aos "eleitos" do maniqueismo.

Vivendo na maior pobreza, entre constantes perseguições, vagavam pelo mundo sem ter residência fixa, copiando verdadeira. mente a vida de Cristo e dos apóstolos.

(6). - Augustug Neander - "General History of Christian Religion and Church" - vol. VIII - pág. 320 . 
Entre os catariu, como entre os maniqueus, havia uma hierarquia entre os "perfeitos" ou eleitos: primeiro, um "bispo"; abaixo dêle, um filius major e um filius minor; finalmente, um "diácono". E' o que afirma Everwin de Steinfeld, escrevendo ao abade de Clairvaux, São Bernardo, a propósito dos cataros da região de Colônia (7).

Muitos dêles haviam sido destinados desde a sua infância. ao ofício de bispo. Por isso haviam recebido educação e alimentação especiais. Em vez de leite, comiam amêndoas; em vez de carne, comiam peixe.

IMuito poucas eram, porém, as pessoas que, pelas suas disposições e tendências destinavam-se a ser "perfeitos". A maioria enfileirava-se entre os "credentes".

Mesmo entre os "credentes" havia uma distinção; a grande massa era constituida de simples "auditores". Dêstes devem ser distinguidos os "catecúmenos"; êstes já haviam sido iniciados nas doutrinas e podiam ser incluidos entre os "credentes". Os "auditores" esperavam receber o consolamentum na hora da morte e, purificados de seus pecados, passariam para a vida celestial.

Muitas vêzes eram chamados, então, os oficiais presidentes da seita para atender os doentes que, na hora da morte, desejavam alcançar o céu. Os doentes, entretanto, deviam comprometer-se a ter uma vida ascética, abstendo-se de leite, do contacto sexual e bebendo exclusivamente água. Se algum daqueles que já haviam recebido o consolamentum houvesse comido algo proibido, devia receber a reconsolatio para que outra vez, fôsse confortado.

Muitos eram aquêles que, tendo recebido o consolamentum, resignavarn-se a morrer de fome; a tal forma de suicídio davam o nome de endura, esperando, assim, passar certamente para o céu, para o reino da Luz; em tôrno do moribundo que havia decidido, voluntàriamente, a morrer, reuniam-se os "perfeitos", animando-o ao sacrifício. Outros afogavam-se ou abriam as veias, ou envenenavam-se com pepinos venenosos. Durante a perseguição fanática contra os cataros, no século XIII, muitos foram os que buscaram, voluntàriamente, a morte.$$
\text { * * * }
$$ \\ EXPANSÃO E PROSELITISMO}

Os cataristas eram zelosos disseminadores dos seus princípios. Em virtude de circunstâncias favoráveis especiais, tais como as disputas entre os Imperadores e o Papa, os cismas entre o. Estado e a Igreja, processou-se de maneira particularmente rápi-

(7). - Idem, obr. cit. - pág. 316.

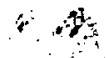


da a difusão de seus dogmas. Durante as disputas entre os Hohenstaufen e o Papa, o catarismo tomou grande vulto na Itália, no Reno. e na França.

Quando as cidades estavam sob o "interdito", a satisfação das: necessidades espirituais dos leigos, levava-os a buscar os heréticos que, assim alargaram consideràvelmente, sua seita.

Como mercadores freqüentaram feiras e mercados e converteram as transações comerciais em oportunidade para introduzirem suas doutrinas entre as multidões que flutuavam nas praças. Entre êstes, muitos foram os que acumularam consideráveis for-.. tunas.

Muitas vêzes os "perfeitos" mandavam seus jovens adeptos: aos grandes centros culturais, tais como Paris, onde se especializaram na arte de refutar a dialética da Igreja Católica e na defesa. de seus próprios dogmas.

A hospitalidade era, para os cataros, um princípio e um de-ver. Como os antigos cristãos, carinhosamente recebiam seus irmãos na fé. Quando peregrinavam pela Itália ou pelo Sul da França, contavam sempre com a recepção carinhosa de todos os ca-. taros. Os perfeitos, em particular, quando viajavam eram recebidos nas casas dos crentes, com tôdas as demonstrações derespeito.

As casas dos membros da seita eram pontos de pregação. Começavam os "perfeitos" pela discussão de verdades práticas, pa-.. ra depois passarem à exposição do Novo Testamento; assim, pre-. paravam-se para a explicação dos pontos de controvérsia entre as: doutrinas do Novo Testamento e as da Igreja Romana.

No Sul da França muitos "perfeitos" educaram irmãs pobres: de cavalheiros da alta nobreza e, assim, puderam disseminar a seita entre as próprias famílias das educandas.

Quando os defensores das doutrinas da Igreja falavam em: milagres dos tempos antigos e modernos, mostravam os cataros as: fraudes e os enganos dêstes milagres. Não poucas vêzes fingiram-se doentes ou endemoninhados para desmascarar os enganos: de certos "fazedores-de-milagres".

Propositadamente entravam em controvérsia com o clero para defender sua fé e desfazer o mal. Os cataristas negavam a autoridade da tradição defendida pela Igreja, o culto às imagens e* aos santos, o valor das peregrinações. Nestas circunstâncias, podem ser considerados precursores do protestantismo e, principalmente, em virtude da prioridade dada à fé, como elemento capital à salvação.

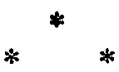




\section{A HERESIA NA FRANÇA E NO VALE DO RENO NOS SECULOS XI E XII}

Antes da adesão em massa do povo ao catarismo, conhecemos, alguns casos individuais de heresia, denunciados, pela primeira vez, na Europa Ocidental, por Gerbert (depois papa Silvestre II), na sua sagração episcopal em Reims. Gerbert procurou esclarecer os católicos sôbre os erros contidos nestas heresias que negavam a ressurreição de Cristo e da humanidace, a divina inspiração do Novo e do Velho Testamentos, a existência de um espírito mau, a legalidade e a santidade do primeiro e do segundo casamentos, a permissão de comer carne, a remissão do pecado original pelo batismo (8).

Em Arras, na Flandres, apareceu um italiano chamado Gudulfo que pregava doutrinas maniqueistas, atraindo grandes multidões. Tendo feito grande número de adeptos, o bispo Reginaldo, que compreendeu o perigo que representava, através de intenso trabalho de pregação, conseguiu persuadir muitos a abjurarem suas novas crenças; assim readmitiu vários dêles ao seu redil.

Em 1043, na diocese de Chalons, estabeleceu-se um grupo de heréticos. Roger, bispo de Chalons-sur-Marne consultou então, a Wazon, bispo de Liége sôbre as medidas que devia tomar contra estas freqüentes reuniões secretas, especialmente as do castelo de Montwimer. Wazon recomendou a sua interferência, instruindo a população contra a heresia e proibindo a comunhão e as relações entre fiéis e heréticos.

No Concílio de Reims de 1149 determinou-se lançar a excomunhão contra os heréticos e todos os que com êles conviviam. As medidas tiveram amplo sucesso, pois em sessenta anos todos os traços do catarismo foram apagados em todo o Norte da França.

Depois do aparecimento de muitos casos isolados de heresias dualísticas, um importante e extenso movimento foi descoberto na Aquitânia e Orléans (1022). Estes heréticos representados pelos monges contemporâneos como sedutores da populaça, negadores do santo batismo e das virtudes da Cruz, simuladores da castidade, foram terrivelmente castigados.

A heresia parece ter sido trazida da Itália por uma certa mulher e conseguiu arrastar não sòmente o povo mas também muitos padres, entre os mais ilustrados. Dentre êstes destacavam-se vários cônegos do capítulo da catedral de Orleans e o próprio confessor da rainha. As reuniōes eram secretas e bem poucos iniciados, delas tinham conhecimento. Tendo se introduzido no grupo dos heréticos, Arefast, cavalheiro do duque da Normandia, entusiasmou-se êste, demasiadamente pela seita, tornou-se indiscreto. (8). - Encyclopaedia of Religion and Ethics - apud. S. R. Maitland, "Facte and: 
Em breve chegaram aos ouvidos do rei as novidades a propósitode concílios de heréticos. .

O rei Roberto, por reclamar já por três vêzes o seu divórcio, entrara em choque com a Igreja, não deixando por isso, de ser zeloso da doutrina. Na véspera do Natal de 1022, foram os esbirros reais em busca de heréticos; os cônegos foram presos e conduzidos perante o rei. Num tribunal composto de juízes leigos e eclesiásticos, procederam a um interrogatório que durou dez horas. Foram, finalmente, condenados a morrer na fogueira e dispersadas as suas cinzas. Pela primeira vez, herejes eram condenados, na França, a tal pena.

A crença, porém, não foi destruida. Grupos de heréticos ressurgiam aqui e acolá. No ano seguinte (1023) constatou-se a presença de heréticos no Artois e em Limoges. Ao mesmo tempo, o bispo de Milão identificava heréticos em Montefort, que, posteriormente, celebrizar-se-ia nas guerras de Frederico Barbarruiva, na Itália.

No século XII ressurge a heresia em três importantes centros: Países-Baixos e Flandres, Alemanha Renana e Provença.

Um certo monge, chamado Tanchelin, iniciou sua pregação na. diocese de Utrecht, estendendo-a depois, a Antuérpia, Cambrai e Liége. Inspirava-se num opúsculo de Sigeberto de Gembloux, muito difundido nos Países-Baixos. Atacava a hierarquia eclesiástica, a autoridade da Igreja, os sacramentos, julgando-se profeta: diretamente inspirado por Deus. Conseguiu fazer diversos discípulos, progrediu o movimento herético e Tanchelin passou a pregar também na Alemanha.

Em Colônia foi aprisionado pelo bispo, mas conseguiu fugir; em 1115 foi morto por um padre.

Entretanto, o movimento não desapareceu com êle. Novos focos de heresia surgiam no Midi da França e depois em Soissons: e na Champagne.

Conexiona-se com o tanchelinismo a pregação do eremita Henri de Lausanne, em Mans, em 1116 e com tôda a agitação da Provença, nesta mesma época.

Os comentadores do tempo, são unânimes em considerá-los francamente maniqueistas. Guibert de Nogent, a propósito da heresia que se pregava em Liége, Soissons e na Champagne diz: "São: das dos maniqueus, tais como Santo Agostinho as descrevia".

Os clérigos de Liége também escreveram a Lúcio III, denunciando erros semelhantes aos do maniqueismo.

Também era maniqueu o bretão Eudes d'Etoille que compareceu ao Concílio de Reims em 1148. São Bernardo em suas cartas e sermões, denunciava seus erros, idênticos aos dos demais heréticos: rejeitava a autoridade da Igreja, a santidade dos sacramentos e pregava uma nova hierarquia. 
Mas Eudes d'Etoille foi mais longe. Mudou o seu nome para Eon e declarou-se profeta Daquele que virá julgar vivos e mortos.

Estes heréticos do norte da França e da Alemanha renana foram acusados de incriveis excessos e deboches, em sermóes violentos de São Bernardo.

Arruinando o reavivamento moral que pregava a reforma gregoriana, deveriam ser implacàvelmente destruídos, seja pela pregação ou seja pelos processos violentos empregados desde Roberto, o Piedoso.

A pregação de nada resultou. Em Colônia, Liége, Soissons foram os heréticos submetidos a tôda a sorte de violências. Segundo Guibert de Noyent, foram levados a um Concílio em Beauvais e depois queimados pelo povo. Eudes d'Etoille caiu prisioneiro do bispo de Saint-Malô; tendo comparecido ao Concílio de Reims (1148), convocado por Eugênio III, foi condenado à prisão perpétua, morrendo pouco depois. Seus discípulos foram mortos (9).

Na mesma época, a Provença foi agitada por um movimento dito docetista, cujos chefes foram Pierre de Bruys e Henri de Lausanne. Suas doutrinas são semelhantes às que foram pregadas na região do Meno, Mosa, Reno e Bretanha.

Pierre de Bruys parece ter conhecido a heresia e se tornado herético na própria Ásia e de lá veio propagando suas idéias e provocando perturbações até o Sul da França. Em 1143 foi queimado pelos habitantes de Saint-Gilles.

Seu continuador foi Henri de Lausanne, antigo eremita místico. Depois de expulso de Mans, esteve em Poitiers, em Bordéus e depois na Provença. Foi aí que encontrou Pierre de Bruys, de quem se tornou discípulo. Vestido de trapos, possuidor de uma oratória vibrante e profética, arrastou as multidões do Languedoc e da Provença. No Concílio de Pisa foi anatematizado, mas depois disto ainda reapareceu pregando no Languedoc.

Pierre de Bruys e Henri de Lausanne foram mais avançados que os demais heréticos. Negavam também a autoridade religiosa e moral da Igreja. Atacavam a maioria dos sacramentos, os símbolos da Paixão, as igrejas, como atentatórios à pregação espiritual do Cristo. Avançando sôbre os demais heréticos, adotaram a livre interpretação dos textos sagrados.

A pregação de Henri de Lausanne aderiram a nobreza e o povo. Para combatê-lo, para lá partiram Alberico, cardeal de Óstia, auxiliado por Geoffroy de Chartres e São Bernardo. Consternava-se Pedro, o Venerável, abade de Cluny, diante do quadro 
tétrico que apresentava o Languedoc durante a pregação de Henri de Lausanne e São Bernardo lamentava a sua sorte:

“Qu'avons nous appris et qu'apprenons-nous chaque jour? Quels maux a faits et fait encore à l'Eglise de Dieu l'heretique Henri? Les basiliques sont sans fidèles, les fidèles sans prêtres; les prêtres sans honneur et pour tout un mot, il n'y a plus que de chrétiens sans Christ. On regarde les Églises comme des synagogues; les sacrements sont plus solemnisées; les hommes meurent dans leurs péchés, les âmes paraissent devant le tribunal térrible sans avoir été reconciliées par la penitence, ni fortifiés par la sainte communion. On va jusqu'à priver les enfants des chrétiens de la vie du Christ en leur refusant la grâce du baptême. $O$ douleur, faut-il qu'un tel homme soit écouté et qui tout un peuple croie en lui!" (10).

Sòmente São Bernardo, pela pureza de seus costumes, pelo vigor de sua pregação, estava capacitado a combater Henri de Lausanne. Em caminho para Toulouse, pregou em Poitiers, Bérgerac, Périgueux, Sarlat, Cahors. Temendo a controvérsia pública com São Bernardo, Henri de Lausanne afastou-se. Em vão São Bernardo tentou inquirí-lo, durante os dois meses de pregação no Languedoc.

Geoffroy de Chartres esperava que o sucesso da pregação de São Bernardo eliminasse para sempre, os focos de heresia, mas enganou-se. Os monges cistercenses de Grandselve que deveriam prosseguir na sua obra, desinteressaram-se. A ação de São Bernardo não criou raizes profundas e foi eliminada em algumas semanas.

$E^{\prime}$ incerto o fim de Henri de Lausanne; desapareceu na sombra de onde surgiu.

Através da influência de Pierre de Bruys e de Henri de Lausanne, o catarismo tomou vastas proporções. Vinte anos depois do desaparecimento de Henri de Lausanne, ressurgiu a heresia no Languedoc.

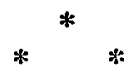

\section{A HERESIA DO LANGUEDOC}

Petit Dutaillis e Aegerter (11) afirmam não encontrar uma explicação plausivel para o sucesso do catarismo no Languedoc. Por que teria sido aí a Meca do catarismo da Euroca Ocidental?

O Languedoc era uma das mais ricas, senão a mais rica das regiöes do reino da França. Toulouse, Béziers, Carcassonne e tôda a Provença prosperavam, graças ao comércio com o Oriente. Tal prosperidade econômica favorecia uma renovação artística e intelectual. O otimismo, a despreocupação, o gôsto pelas artes e pela literatura, indicavam abundância de bens materiais .

(10). - Idem, obr. cit. - pág. 97.

(11). - Petit Dutaillis et P. Guinard - "L'Essor des états d'Occident" - (Co1. Glotz) - vol. IV pág. 60 e Emmanuel Aegerter - "Les héresies du Moyen Áge" - pág. 41. 
Foi na Provença que floresceu a literatura trovadoresca, cujo tema principal era o amor e o culto à mulher amada. Os grandes nobres enriquecidos tornaram-se "mecenas" protetores dos troubadours. Era uma sociedade brilhante que amava as delicadezas de espírito, os torneios poéticos, o luxo, o confôrto.

Sôbre as côrtes principescas fazia-se sentir fortemente a influência muçulmana, principalmente nos costumes e na vida social daquela gente que amava o belo e o bom.

Eis porque, sob o ponto de vista religioso, não se compreende que tenha sido o Languedoc, a terra de eleição do catarismo, uma religião que pregava a renúncia do amor, do confôrto, do apêgo aos bens materiais, uma religião de morte e não de vida.

Lembremo-nos, entretanto, que os seus suzeranos, os rudes e grosseiros suzeranos, eram os senhores do Norte, os defensores da Igreja e da Fé Católica.

Assim, a adesão à heresia é também, de certa forma, uma atitude de reação contra aquêles que os sujeitavam.

Tudo conduzia o Languedoc à separação, animada pelos seus insubmissos senhores. A sua prosperidade econômica dava-lhes foros de independência.

E' bem provável que a ocupação da região pelos gôdos arianos tenha sido, pelo menos em parte, o ponto de partida para a tendência herética de seus habitantes. Como reação às guerras de Clovis contra os herejes, acentuou-se esta inclinação à heresia, favorecida por uma aliança entre os gôdos do Languedoc e a Espanha visigótica. Um espírito de aversão e de resistência aos francos invasores tornou-se uma tradição entre os gôdos conquistadores e o elemento nativo que havia sofrido profundas transformações em virtude dos cruzamentos étnicos.

A conquista muçulmana da Espanha não modificou grandemente a situação, no que se refere à oposição religiosa; de certo modo, islamismo e arianismo assemelhavam-se na comum oposição à Igreja Romana, na negação da divindade de Cristo, no que se refere à veneração de santos, imagens e relíquias.

A influência dos muçulmanos sôbre a região não foi imperceptível; vários críticos indicam transformações da linguagem, da arquitetura, das indústrias sob o influxo dos sarracenos.

Inclinava-se, assim, favoràvelmente a população, que não era estranha às heresias, à pregação de paulicianos embebidos das doutrinas do maniqueismo.

No século XII a Igreja Católica reconheceu que, em virtude da influência da ocupação gótica e dos sarracenos sôbre os habitantes da Septimânia, e especialmente sôbre o condado de Toulouse, herdaram êstes uma tendência herética da qual muito poucos haviam se libertado (12).

(12). - Achille Luchaire - "Innocent III e la Croisade contre les Albigeois" - pág. 278. 
Os dogmas do catarismo que, pregados em diversos pontos do território francês, haviam causado profundas perturbações, por vias mais ou menos obscuras, haviam atingido o Languedoc. Aí obtiveram grande sucesso as pregações de Pierre de Bruys e seu discípulo Henri de Lausanne.

O catarismo penetrou em tôda a sociedade, de alto a baixo; nos nobres, ricos, camponeses e burgueses. Os camponeses, os operários, aplaudiam a seita porque atacava a potência temporal do clero, os dízimos, os impostos e tôda a sorte de taxas que recaiam sôbre os fiéis (13).

Havia mesmo, um plano concebido pelos "perfeitos" para atrair tôda essa massa do proletariado rural e urbano. Segundo Jean Guiraud (14), para conquistar os artezãos, os "perfeitos" organizaram oficinas, verdadeiros patronatos modernos, onde, além do ofício, ensinava-se a doutrina aos jovens. Eram numerosas no burgo de Fanjeaux.

Raimundo de Saint-Gilles, conde de Toulouse, Raimundo Roger, conde de Foix, Raimundo Roger, conde de Béziers e Carcassonne, Gastão, visconde de Béarn, Bernard de Comminges, eram favoráveis à heresia, seja por "snobismo" ou gôsto de oposição, seja pelo desêjo de secularizar os bens da Igreja (15).

Mesmo entre as damas da nobreza, muitas foram as que deixaram seus bens e suas famílias para se tornarem cataristas fervorosas. A condessa de Foix e as irmãs do Conde, deixaram a família e abraçaram a heresia.

Nas cidades, os burgueses aderiram em massa ao catarismo. No Norte da Itália, a grande massa de cataros era constituida de burgueses e artezãos, cujas oficinas eram centros de proselitismo.

Foi o campo, porém, que forneceu o maior número de adeptos. De há muito abandonados dos socorros espirituais da Igre$\mathrm{ja}$, ansiosos por uma nova intensidade de vida espiritual, aderiram à nova pregação, feita em linguagem compreensível, por homens que apresentavam uma pobreza igual à sua. Os camponeses, pràticamente em massa, aderiram à pregação da nova seita .

Sem dúvida alguma, o catarismo tem um aspecto social. Descobre-se isso, apesar da obscuridade dos textos. Na Chanson de la Croisade contre les Albigeois, mesmo em sua primeira parte que foi escrita por um adepto fervoroso da Cruzada, sente-se que há uma revolta da burguesia, dos artezãos e camponeses contra a Igreja, contra o regime social e político, contra tôda a forma de opressão, uma luta pelos direitos adquiridos por uma classe que tende a se sobrepor. E', sem dúvida, uma luta de classes, disfarçada sob a forma de luta religiosa.

(13). - Jean Guiraud - "Saint Dominique" - pág. 19.

(15). - Petit Dutaillis et P. Guinard - obr. cit. - pág. 61. 
Tais progressos havia alcançado o catarismo em tôda a Provença, que os aderentes desta seita passaram a ser designados pelo nome de uma das suas mais importantes cidades - Albi. Os granđes centros de heréticos, além de Albi, foram Toulouse e Carcassonne.

Esta rápida difusão da heresia culminou com a reunião de um Concílio de cataros da região, presidido pelo chefe dos paulicianos de Constantinopla, Nicetas (ou Niquitas), que era tido como o papa do catarismo.

Este concílio reuniu-se em 1167 em São Felix de Caraman, nas proximidades de Toulouse. A sua importância despertou imediatamante profundas apreensões da Igreja Católica. Nicetas confirmou aqui, cinco novos bispos da Septimânia e condados adjacentes, entre os quais estava Sicard de Cellerier, bispo de Albi (16). Tal concílio parece ter dado à seita maniqueista, suas mais agressivas formas.

Em 1201 um outro "perfeito", Juliano de Palermo, apareceu em Albi. Pela sua oratória eloqüente, que já havia arrastado multidões na Albânia, foi recebido de braços abertos por muitas das cidades mais importantes da Septimânia.

Outras circunstâncias locais, entretanto, favoreceram a disseminação da heresia.

A atitude dos senhores feudais do Sul da França em relação à Igreja, tornava-se cada vez mais inamistosa, ainda que, bem poucas vêzes chegassem a ser hostis. Eram conflitos com bispos, ou então com mosteiros adjacentes, isentos de contrôle local em virtude de cartas pontificais. Da mesma natureza eram os conflitos dos habitantes das cidades muradas.

A atitude dos burgueses do Languedoc chegou a ser, por vêzes, profundamente hostil à Igreja, isto porque ela se mostrou sempre profundamente contrária ao movimento comunal. E' o caso, por exemplo, que ocorreu com o bispo de Lodève, cujo palácio episcopal foi assaltado pelos habitantes da cidade que dêle exigiam privilégios.

Interêsses comuns promoveram a aproximação dos senhores e burgueses, em virtude da hostilidade comum contra a Igreja, à qual eram absolutamente indiferentes.

De um lado, a burguesia ansiosa pelas liberdades comunais; de outro lado, a nobreza desejosa de estender seu domínio sôbre os mosteiros e foros eclesiásticos independentes contra os quais lutava a mesma burguesia. Dois interêsses que, em condições normais, seriam antagônicos, e que se unem diante de um inimigo comum, a Igreja.

(16). - Encyclopaedia of Religion and Ethics - apud. Vignier, "Histoire de I'Eglise" - pág. 280 . 
De todos os vassalos de Luiz VII, era o conde de Toulouse, o mais independente. Em 1154, Raimundo V, se casou com Constança, irmã de Luiz VII e êste casamento trouxe importantes modificações nestas relações. Pouco depois, e pela primeira vez em um século, um monarca francês, visitou o Languedoc. Em 1158 Foi chamado para repelir as fôrças de Henrique II da Inglater -a, do condado de Toulouse. Mudou-se, então, a sua política e de seu sucessor, Filipe-Augusto: cultivar, direta e amistosamente as relações com o clero destas províncias do Sul. Uma série de cartas garantiam privilégios para os bispos de Maguelonne, Narbonne, Nimes, Uzés e Agde e algumas abadias de Toulouse. Nestas condições, quanto aos privilégios e independência, os senhores do Languedoc, estavam em pé de igualdade com os senhores locais. De agora em diante o rei e o papa eram seus suzeranos (17).

Outra questão de importância capital e que dificultou a repressão à heresia, ou pelo menos retardou, foi a implantação da suzerania aragonesa sôbre grande parte dos senhorios que formavam o ducado da Provença: em 1172, o condado do Russilhão e em 1187 a vassalagem dos condados de Béarn e Bigorre.

Os acréscimos territoriais da corôa aragonesa, a despeito de territórios do Sul da França, prosseguiram no reinado de Pedro II, que uniu à sua corôa, o condado de Montpellier, por casamento com a herdeira dêle, Condessa Maria, em 1204. Além disso, estava estreitamente ligado por laços de família ao novo conde de Toulouse, Raimundo VI.

"Et, puis qu'il est mon beau frère, car il a épousé ma soeur (Eléonore d'Aragon), et puis que j'ai marié mon autre soeur a son fils (Saucie d'Aragon), j'irai les aider contre cette gente maudite qui les veut deshériter". (Palavras de Pedro de Aragão) (18).

À corôa aragonesa não interessava a intervenção dos ambiciosos nobres franceses dentro dos territórios que constituiam os seus domínios, os quais, a pretexto de repelir a heresia, queriam apoderar-se das terras do Sul da França.

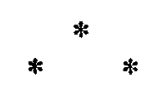

\section{A REAÇÃO DO ESTADO E DA IGREJA}

Para a ordem social constituida, o catarismo representava uma ameaça, não só aos dogmas da Igreja Católica, como também a tôda a estrutura feudal. Por isso foi combatido. Primeiro pela pregação, depois pela violência.

(17). - Ibidem - apud. A. Luchaire - "Instituitions des prémiers capétien" - pág. 280. (18). - "La Chanson de la Croisade contre les Albigeois" - pág. 31. 
A aparente ou real pobreza dos "perfeitos", era uma contradição com a vida brilhante e mais ou menos livre do clero da época e especialmente do clero francês. Nem por hipótese faria lembrar os primeiros apóstolos do cristianismo que, por fôrça, os "perfeitos" queriam imitar. E o faziam com certa propriedade: suas longas barbas, roupas em frangalhos, nomadismo inveterado, oratória profética, tudo isto dava uma idéia dos primeiros apóstolos.

Os dogmas do catarismo, além disto, investiam contra tôdas as verdades ensinadas por Roma. A Cosmogonia, a Cristologià cataras, revolucionavam as concepções romanistas. A afirmação mais ou menos clara da inexistência do inferno, baseada na suposição de sucessivas metempsicoses, o repúdio, portanto, da doutrina do purgatório, a condenação ao culto das imagens e à mediação dos santos, a simplicidade e a austeridade do culto, tudo isto ia contra o que tradicionalmente se ensinava.

Os princípios do catarismo condenavam os derramamentos de sangue, o serviço militar e os juramentos. Estavam, pois, ameaçadas as instituições feudais, cujas bases eram os juramentos de fidelidade e a prestação de serviços de hoste e côrte, de vassalos a suzeranos. Os reis e os príncipes não podiam contar com a fidelidade de grande massa da população dos maiores centros do catarismo.

Proibido o casamento, a humanidade estava total ou parcialmente ameaçada pela cessação da natalidade. Felizmente êste princípio era adstrito aos "perfeitos" que, como já vimos, constituiam minoria absoluta. Aos "credentes" eram permitidas as alianças matrimoniais e a coabitação. Preservava-se, assim, o futuro da espécie humana.

A Igreja, os reis e os princípes viam-se, pois, na contingência de combater tais heréticos, ainda que muitos impecilhos se opusessem a uma rápida ação contra êles.

A Igreja não tomou, desde o princípio, uma atitude agressiva contra os heréticos. Muitos dos grandes santos do tempo reconheciam o perigo representado por êles, mas aconselhavam primeiramente, uma vida de piedade para o clero e depois a instrução dos fiéis contra os erros contidos nas heresias.

Hildegarda, abadessa do mosterio de Mont St. Ruppert, perto de Binggen, enviava ferventes apelos ao clero de Colônia, pedindo a destruição "dêstes homens nefandos, piores que os judeus e tão maus quantos os saduceus" (19), desdenhosos das ordens divinas, hipócritas que fingiam jejuar e viviam em incestuosa luxúria, desprezadores das leis de Deus emanadas da voz de Moisés e dos profetas e do próprio Cristo. Recomendava, porém, que não se punisse os cataros com a morte, respeitando neles, como criaturas, a imagem do próprio Deus.

(19). - Encyclopaedia of Religion and Ethics - pág. 279. 
O piedoso Pierre Cantor, professor de Teologia de Reims e de Paris, declarou-se contra a punição por morte, dos cataros. Opunha-se aos ordálios, aos julgamentos de Deus, como instituições contrárias ao espírito da cristandade e da Igreja; vigorosamente atacava o poder arbitrário, a tirania sôbre a consciência, as quais caracterizavam os processos contra os cataros.

Fazia lembrar a tolerância dos pagãos em relação ao cristianismo, quando exigiam a negação do nome de Cristo e oferendas a seus deuses.

"A simpatia e a tolerância em relação aos heréticos poderá certamente, triunfar sôbre o fanatismo e a Igreja não será acusada de crueldade no tratamento dos cataros" (20).

Quando Wazon, bispo de Liége, respondeu à consulta de Roger, bispo de Chalons-sur-Marne a propósito dos heréticos de Montwimer, recomendou-lhe, expressamente que se abstivesse do uso do gládio temporal. Fazia lembrar, como já o fizera algumas vêzes, anteriormente, Pierre Cantor, que Cristo havia recomendado que se deixasse crescer o jôio no meio do trigo para se fazer a separação, quando fôsse colhida a messe (21).

Também o grande São Bernardo de Clairvaux recomendava a tolerância e a prudência no tratamento dos heréticos e a educação dos fiéis. Em um sermão dizia: "Eles (os heréticos) devem ser atraídos não pelas armas, mas com argumentos pelos quais seus erros serão expostos; e êles próprios, reconciliados, se possível, com a Igreja Católica serão conduzidos à verdadeira fé; para tanto, é seu desêjo (da Igreja) que possam ser salvos todos os homens e trazidos ao conhecimento da verdade" (22).

O melhor seria, pois, a instrução sistemática e cuidadosa dos fiéis, pois é muito raro e muito difícil converter um herético, mas é muito fácil e comum subverter o fiel.

As inúmeras preocupações de ordem política e principalmente a velha "Questão das Investiduras" impediram a Igreja de tomar atitude decisiva contra os heréticos. Assim, durante cêrca de dois séculos, apenas medidas isoladas foram tomadas contra êles. Nos Concílios de Toulouse de 1119 , no de Latrão de 1139 , no de Reims de 1148, no de Montpellier de 1162, no de Tours de 1163, diversas prescrições visavam o ataque por todos os meios contra as heresias e principalmente contra o catarismo. Mas nenhuma medida positiva foi tomada.

Durante décadas a pregação dos padres, bispos e legados pontifícios mostraram-se infrutíferas. Em 1167. os cataros chegát ram ao extremo, como já vimos, de reunir o Concílio de São Felix de Caraman, sob a presidência de Nicetas, bispo pauliciano de Constantinopla.

(20): - Augustus Neander - obr. cit. — pág. 316.

(22). - Augustus Neander - obr. cit. - págs. 325-326. 
Em 1177, Raimundo de Toulouse, escrevendo ao Capítulo Geral de Cister, a propósito dos progressos da heresia dizia o seguinte: "Ela divide nas famílias, marido e mulher, pai e filho, genro e nora. Padres mesmo, se deixavam contaminar. As Igrejas estão abandonadas e em ruínas. Recusa-se o batismo; insulta-se a Eucaristia, nega-se a penitência. Não se deseja falar sôbre a criação do homem, nem da ressurreição da carne e o que é de espantar, inventam-se duas fontes originais da existência. As pessoas mais influentes do meu domínio se deixaram contaminar, a massa seguiu o seu exemplo e perdeu a fé a tal ponto que não há mais fôrça para abafar o mal. O gládio espiritual nada pode contra o gládio material (23).

"Em Toulouse os heréticos eram tão numerosos que êles escarneciam e mostravam a dedo na rua, aquêles que ainda se conservam fiéis à Igreja Católica" (24).

Em 1178 Luiz VII e Henrique II, tentaram organizar uma primeira cruzada contra os albigenses; esta primeira tentativa, porém, fracassou. Foram enviados, então, pregadores leigos e eclesiásticos, encarregados de pregar e perseguir os propagadores da heresia. Coube ao legado Pedro de Pavia, dirigir a missão, que não trouxe resultado algum. Certos heréticos importantes foram delatados, mas a heresia continuava a propagar-se entre tôdas as classes sociais.

Após a reconciliação entre Alexandre III e Frederico Barbarruiva, reuniu-se em Latrão, em 1179 , o Terceiro Concílio dêste nome. Nele ficou estabelecido proceder-se rìgidamente contra os heréticos, especialmente contra os cataros.

A situação, assim, complicava-se cada vez mais. Os cataros que até então tinham assumido uma atitude puramente defensiva, passam agora à ofensiva, dirigidos por alguns nobres de alta linhagem. Raimundo Roger, conde de Foix, vivia cercado de heréticos. Expulsou as religiosas do convento de Pamiers e se não dirigiu, pelo menos não tomou conhecimento do assalto à Igreja de Urgel.

Em Verona, Lúcio III e Frederico Barbarruiva decidem-se a atacar severamente os heréticos. $O$ curto pontificado dêste papa não permitiu que fôssem tomadas as medidas premeditadas.

Em 1198 recebeu a tiara o grande Inocêncio III. Antes, porém, de tomar qualquer forte medida contra os heréticos, ainda pensou ser possível a conversão dêstes por meio de intensas pregações feitas por missionários de comprovada piedade e zêlo, a fim de que se pudesse recuperar o terreno perdido por um clero desacreditado. Este método foi empregado para convencer os cataros de Pamiers, Béziers, Montreal. Os resultados foram insignificantes.

Em 25 de março de 1199, assim se expressa Inocêncio III, depois de infrutiferas tentativas para a conversão dos heréticos pela

(23). - Gustave Schnüer — obr. cit. - pág. 511.

(24). - Ibidem, pá. 511. 
persuasão: "Se aquêles que cometem crime de lesa-majestade são punidos, segundo a lei, pela pena de morte e pela confiscação de seus bens, se nada se deixa aos filhos além da vida, que merecem então, aquêles que, desertando de sua fé, ofendem o Filho de Deus? Serão, pela pena imposta pela Igreja, separados de nosso chefe, Jesús-Cristo, e privados de seus bens terrestres. Porque o crime de lesa-divindade é bem mais infame que o de lesa-majestade" (25).

Mas medidas drásticas, não as tomou imediatamente. Resolveu mais uma vez lutar pela reconquista dos heréticos, através da prédica. Dêste empreendimento foram incumbidos Pierre Castelnau e Raoul, ambos da ordem de Cister e mais tarde o próprio abade Arnaud Amalric, os quais em 1203, partiram para o Sul da França.

De acôrdo com as instruções do próprio papa, desenvolveram sua missão no sentido de combater não só a heresia, mas também o clero corrupto e desmoralizado que era o principal responsável pelas proporções que o catarismo tomou nessa região.

Como o papa conhecia as dificuldades de tal missão, foram encarregados também do trabalho entre os heréticos, o bispo de Osma, D. Diego de Acevedo e seu cônego, Domingos de Guzmán .

Domingos de Guzmán conhecia a fundo o movimento religioso do seu tempo. Possuidor de uma cultura extraordinária e de grande eloqüência, aliados a uma profunda unção religiosa, não possuia, entretanto, aquela simplicidade cativante de São Francisco de Assis.

Como teólogo, desejava conduzir os heréticos mais pela razão que pelos sentimentos, mostrando a êles a superioridade real dos ensinamentos da Igreja.

A atitude dêstes pregadores não foi imperiosa, nem provocante. Modestamente vestidos, de pés nus, sem bagagens, movidos por um zêlo ardente e uma fé ativa, buscavam os heréticos como - faziam os "perfeitos" em suas peregrinações. Assim pregaram diante do povo durante dois anos.

Os resultados da pregação foram insignificantes. Poucos foram os cataros que se converteram. Mas outras conseqüências posteriores é que importam: 1). - a fundação das ordens mendicantes destinadas à pregação ao povo. Esta idéia partiu do bispo de Osma, mas foi concretizada por Domingos de Guzmán; 2). - a instituição de uma jurisdição especial eclesiástica para a perseguição aos heréticos.

Para o sucesso da ação dos pregadores havia necessidade do apôio dos reis e da nobreza.

Para a realeza, a sublevação do Languedoc era grave ameaça politica, muito mais que um problema religioso. Despertaramse as ambições de algumas potências estrangeiras que teriam tođo

(25). - Ibidem - obr. cit. - pág. 619. 
- interêsse em sustentar ou proteger os príncipes heréticos. De um lado, Pedro de Aragão com títulos legítimos de posse de alguns dos mais importantes feudos da região e por outro, Joãosem-Terra que também poderia reivindicar alguma coisa baseada na herança de Aquitânia, ou pelo menos estimular a rebelião para enfraquecer seu rival, Filipe-Augusto.

A "chefia da Cruzada "espiritual" caberia ao rei da França, que era o mais poderoso monarca cristão e, além disso, o que mais fiel se revelara à ortodoxia católica. Tanto Luiz VII como FilipeAugusto reconheciam o perigo do maniqueismo e a expedição anteriormente planejada, de Luiz VII e Henrique II havia fracassado.

Filipe-Augusto ao ser convidado por Inocêncio III para dirigir a cruzada, exigiu do papa uma trégua de dois anos com Joãosem-Terra. Filipe-Augusto havia alargado os seus domínios a despeito dos territórios inglêses do Loire e do Poitou. Mas o papa não podia garantir tal trégua pois havia excomungado Joãosem-Terra.

"Em relação aos heréticos professava o rei Filipe os mesmos sentimentos de seus contemporâneos; não hesitaria em levar a guerra contra êles e queimá-los nas praças públicas, mas no momento tinha seus interêsses particulares: " $E$ '-me impossível responder a Inocêncio III, recrutar e manter dois exércitos, um para defenderme contra o rei da Inglaterra e outro para marchar contra os albigenses. Que o Senhor Papa encontre dinheiro e soldados e que êle obrigue, sobretudo, os inglêses a permanecerem em paz e nós veremos..." (26)

A situação política do Sul da França era bastante complexa. A corôa de Aragão havia herdado a suzerania sôbre os territórios que faziam parte do ducado de Provença, em 1172 e em 1187 recebia a vassalagem dos condados de Béarn e Bigorre. Em 1204 a corôa aragonesa recebeu novos acréscimos com o casamento de Pedro de Aragão com Maria, herdeira do condado de Montpellier. Os reis de Aragão nunca puderam estabelecer suzerania definitiva sôbre êsses territórios, em virtude das grandes dificuldades políticas e principalmente por causa das perturbações resultantes da expansão do catarismo.

A velha rivalidade entre a Hispânia e a Gótia de um lado, e os francos de outro, sempre vinha à tona.

Pedro II percebeu logo a ambição daqueles que, a pretexto de uma guerra religiosa desejavam pilhar domínios dos quais era suzerano. Necessàriamente deveria defender seus interêsses. Daí por-se ao lado dos heréticos mas, para demonstrar sua fidelidade religiosa e seus sentimentos católicos, a separação entre a questão religiosa e a questão política, em novembro de 1204 foi a Roma

(26). - Emest Lavisse - "Histoire de France - Des Origines à la Révolution" Tome III - 1e. partie - pág. 266. 
a fim de ser coroado pelo papa, ao qual prometeu defender a fé católica, respeitar a liberdade e a imunidade das Igrejas, perseguir os herejes, fazer justiça em sua terra.

"Porẻm, em seguida, fêz uma declaração muito comprometedora: a de ser vassalo do papa, oferecendo-lhe em feudo os reinos de Aragão e Catalunha que lhe pagariam anualmente, um tributo em troca do qual o papa e seus sucessores defenderiam os reis com sua autoridade apostólica" (27).

Assim, passaram a ser feudos do papa, grande parte dos territórios do Sul da França, que pertenciam à corôa de Aragão e onde a heresia tomara maior vulto.

Diante das excusas de Filipe-Augusto, da impossibilidade de Pedro de Aragão tomar a ofensiva contra seus próprios interêsses. o papa viu-se na contingência de buscar outro aliado. Esse aliado deveria ser Raimundo VI, conde de Toulouse que, com seus repetidos retornos à fé católica, chegara a iludir o papa. Mas Raimundo era um aliado perigoso em virtude de suas dúbias atitudes religiosas. Ora ouvia, com unção, os pregadores católicos, ora atendia aos heréticos. Na realidade, era um comediante hábil, capaz de se sair bem ante as invectivas daqueles que dêle duvidavam.

Graves acontecimentos, porém, se prenunciavam. Numa de suas entrevistas com o legado Pierre de Castelnau, com êle discutiu violentamente a propósito da perseguição aos heréticos. Em seguida (15 de janeiro de 1208), Pierre de Casielnau foi assassinado numa fria noite de inverno, na porta de uma estalagem, ès. margens do Ródano, no caminho de Saint-Gilles, por um escudeiro de Raimundo VI (28).

Este incidente permanece envolvido em obscuridade; entretanto, segundo as declarações de Inocêncio III, Raimundo tinha convidado Pierre de Castelnau, fingindo-se arrependido, a fim de que o legado recebesse a sua submissão. A caminho de SaintGilles então, é que foi assassinado. Constava mesmo, que Raimundo havia feito presentes ao escudeiro (29).

Imediatamente, Inocêncio III excomungou Raimundo e todo o seu território (10 de março de 1208), desligou de fidelidade os súditos de seus domínios e, desligando-os de seus juramentos de fidelidade, ofereceu os seus domínios a quem os quisesse conquistar.

Entretanto, o papa não proclamou imediatamente a cruzada. Primeiramente confiou aos dominicanos o dever de pregá-la por todo o reino e de fazerem um quinto apêlo a Filipe-Augusto para que êle dirigisse a cruzada. Inùtilmente, porém. Só em 1209 é que a cruzada foi decretada.

Despertaram-se as ambições. De todos os lados surgiram homens desejosos de remir seus pecados pelas indulgências da cru-

\footnotetext{
(27). - Altamira y Crevea - "Histí:a de España y de la civilización espafiola" -

(28). - Petit Dutaillis et P. Guinard - obr. cit. - pág. 67.

(29): - Encyclopaedia of Religion and Ethics - pág. 283.
} 
zada e de ganhar grossos proventos em ricas províncias. A' cruzada reuniu-se em Lião e compôs-se de elementos franceses vindos do Norte, do Centro, do Sul e do Oeste. Descendo o vale do Ródano, atingiram o Languedoc. E' a primeira invasão puramente francesa nesta região. As velhas rivalidades se acirraram.

Filipe-Augusto não chefiou a cruzada, pois não concordou com o deserdamento de seu vassalo Raimundo, antes de ter sido pùblicamente julgado por crime de heresia, declarando também que o papa havia se excedido em seus poderes, confiscando as terras do conde.

"Condamnez-le comme héretique, alors seulement vous aurez le droit de publier la sentence et de m'inviter, moi, le suzerain du comté pour convaincu d'héresie" (30).

Mas, se o rei da França não participou da Cruzada, a ela afluiram vassalos seus em grande número, com o conhecimento e o assentimento do rei.

A primeira fase da cruzada foi realmente uma guerra religiosa; dirigiu-a diretamente o legado papal, Arnaud Amalric, abade de Cister.

Não coube, pois, o comando aos grandes senhores tais como o duque da Borgonha, o conde de Nevers ou o conde de SaintPol; o legado Arnaud Amalric ao receber o comando passou-o imediatamente ao seu tenente, Simon de Montfort, um pequeno senhor da Ile-de-France: Simon de Montfort estava talhado para ser o chefe, pois era um cristão fervoroso e já havia se reveladu soldado valente nas Cruzadas à Terra Santa; ao lado do fanático fervor, tinha uma ambição sem limites.

O troubaciour que descreve as glórias dêste exército, em sua Chanson de la Croisade contre les Albigeois, afirma, com evidente exagêro, que o exército era composto de 20.000 cavaleiros armados e 200.000 infantes, ligados pelo estandarte da Cruzada (31).

Diante da invasão e do abandôno em que se achavam as populaçōes meridionais, generalizou-se ali, o desânimo. O próprio Raimundo resolveu submeter-se e no dia 18 de julho de 1209, depois de uma cerimônia de humilhação, reconciliou-se com a Igreja na Catedral de Saint-Gilles. Foi obrigado a jurar sôbre os Evangelhos, na presença de relíquias, a expelir os judeus, proclamar as. "tréguas de Deus" e a participar da Cruzada.

Não foi aceita, entretanto a submissão do visconde de Béziers, apesar de ser sobrinho de Raimundo e genro de Pedro II de Aragão.

Por isso, no dia 22 de julho de 1209, iniciou-se o cêrco de Béziers pelas tropas do arcebispo de Bordéus e do bispo de Puy. Os sitiados resistiram heròicamente, mas finalmente a cidade foi

(30). - Ernest Lavisse - obr. cit. - pág. 268.

(31). - Encyclopaedia of Religion and Ethics - apud. Fauriel "Fistoire de la Poésie: Provençale" — pág. 283. 
tomada pelos cruzados, pilhada e incendiada. Nem velhos, nem mulheres e crianças, inocentes ou culpados, escaparam à sanha dos soldados fanáticos. Ao pé dos altares, inocentes eram assassinados. Nas ruas corria sangue e as patas dos cavalos pisavam pilha de cadáveres.

Aos clarões das fogueiras onde se queimavam cadáveres e sob as tétricas sombras dos patíbulos armados às margens das estradas, prosseguiu o exército na sua marcha sinistra. A 5 de agôsto atingiram Carcassonne. O jovem Raimundo Roger, conde de Béziers e Carcassonne tentou resistir. Novas atrocidades; calculase em 20.000 as vítimas, inclusive 7.000 refugiados numa só Igreja. Os seus habitantes foram obrigados a abandonar a cidade seminus. Pierre de Cernay foi testemunha ocular das violências e do fanatismo selvagem de Simon de Montfort.

"Le roi d'Aragon, qui a rejoint l'armés des croisés, tente de sauver les asiegés; mais les conditions de l'abé de Citeaux sont telles que le vicomte de Béziers décide de continuer la resisténce; quelques jours après il est fait prisionner par ruse et les Croisés entrent dans Carcassonne" (32).

Narbonne salvou-se depois de uma execução em massa de cataros.

“...Le comte Raimon de Toulouse, ne pouvant obtenir de l'abbé de Citeaux l'absolution qu'il lui demande, se rend auprès du Pape et, des son retour, livre a Simon de Montfort le Chateau Narbonnais" (33).

Montpellier reafirmou sua fidelidade à Igreja; entretanto, cêrca de quinhentas cidades e castelos foram destruidos. A Septimânia era um verdadeiro deserto.

Em dois anos foi submetido todo o Languedoc. As sucessivas vitórias de Montfort reduziram os domínios do Conde de Toulouse, a Toulouse e Montauban.

Completava-se a usurpação dos domínios; nenhum dos nobres participantes da cruzada aceitou os despojos da conquista; "Simon de Montfort resignou-se à desonra de aceitá-los" (34).

Ao legado Arnaud Amalric coube o arcebispado de Narbonne e entre os cruzados vindos do Norte, foram distribuidos os benefícios. A Igreja sucedeu à feudalidade meridional na exploração da região (35).

Era desencorajante a situação econômica do território para o qual Simon havia sido chamado a administrar. Não havia dinheiro para os poucos cavaleiros que havia trazido consigo. O pontífice

(32) - "La Chanson de la Croisade contre les Albigeois" - pág. 15.

(33). - Idem obr. cit. - pág. 17.

(34). - Ernest Lavisse - obr. cit. - pág. 26.

(35). - Petit Dutaillis et P. Guinard. - obr. cit. - pág. 67. 
não pođia ajudá-lo porque estava preocupado com a quarta cruzada e então apelou para o Imperador Oto e para Pedro de Aragão, invocando a sua assistência.

Pedro de Aragão, porém, não podia conformar-se com a usurpação de Simon de Montfort; os senhorios do Norte da Espanha estavam estreitamente entrelaçados e a expansão de Simon de Montfort no Languedoc inquietava-o. Daí o interêsse que Pedro de Aragão tinha em proteger seu cunhado, o conde de Toulouse.

Depois da mediação dos legados pontificais, Pedro de Aragão concordou em reconhecer Simon de Montfort como senhor de Béziers e Carcassonne, desde que Jaime, filho de Pedro se casasse com. uma filha de Simon de Montfort. Montfort cuidaria da educação de D. Jaime, que neste tempo contava dois anos de idade. Mais tarde recusou-se a cumprir as condições do convênio.

Entretanto, o conde de Toulouse, apesar de reconciliado com a Igreja não conseguiu entender-se com Simon de Montfort que tentava apoderar-se também de seus domínios.

Pedro de Aragão, para evitar maiores perturbações, tentou regular pacificamente a questão, restabelecendo seu protetorado sôbre a Provença. No Concílio de Lavaur, pediu que se fizesse justiça restituindo terras e castelos aos condes de Toulouse, de Foix e de Comminges e defendeu os interêsses de Raimundo Roger, conde de Béziers e Carcassonne, contra as arbitrariedades de Montfort, màs encontrou forte oposição dos grandes senhores. O desêjo dos nobres era ver a ruína do conde de Toulouse antes que êle se reconciliasse com o papa. A representação dos nobres, enviada ao Concílio de Latrão, em têrmos de urgência, mudou completamente a atitude de Inocêncio III. Escrevendo a Pedro de Aragão diz que "os defensores da Igreja contra a heresia, são mais perigosos que os próprios heréticos" (36).

Depois de uma última tentativa fracassada junto a Filipe-Augusto, Pedro de Aragão declarou-se abertamente a favor de seus súditos albigenses e foi levado, então, à extrema resolução de declarar guerra apoiando o conde de Toulouse e todos os outros nobres do Sul que haviam sido despojados de suas terras pela nobreza ambiciosa de França. Antes, porém, conseguiu, como medida preliminar de capital importância, assegurar-se de que Filipe-Augusto não participaria da guerra, bem como seus filhos, em apôio a Simon de Montfort (37).

Uma só batalha marca o reinício da guerra contra Simon de Montfort. Nos arredores da aldeia de Muret deu-se o encontro decisivo. As operações mal dirigidas por Pèdro de Aragão, esgotado pelos excessos da noite precedente, resultaram num terrivel fracasso. Nela morreu Pedro de Aragão, em 13 de setembro de

(36). - Encyclopaedia of Religion and Ethics - pág. 285.

(37): - Altamira y Crevea - obr. cit. - pág. 392. 
1213. Despojado de suas terras, Raimundo refugiou-se na côrte de João-sem-Terra, onde foi muito bem recebido.

Foram duríssimas as condições impostas ao conde de Toulouse:

"Ils ne percevront plus sur les chemins d'autres péages que ceux anciennement établis et donneront chaque année quatre deniers toulousains aux "mainteneurs de la paix" établis par les croisés; les usuriers renonceront au prêt à usure et s'ils ont fait quelque gain, ils le rendront tout d'abord; si le comte de Montfort ou les croisés chevauchent sur les terres du comte de Toulouse et prennent des biens lui appartenant, on ne devra point s'y opposer" (38).

O ambicioso Simon de Montfort desejava tornar-se conde de Toulouse; para tanto necessitava do apôio do rei e do papa. A aquiescência do rei, êle a teve; o papa, porém, foi obrigado a conformar-se com fatos já consumados.

Filipe-Augusto, convidado ainda uma vez para dirigir a cruzada, recusou-se pretextando o perigo das ameaças de João-semTerra e a coalisão européia. Em seu lugar foi seu filho Luiz.

Luiz obrigou o conde de Narbonne a reconhecer Montfort como duque e afastou as pretensões do legado Arnaud Amalric que, por inveja, tornou-se inimigo de Simon de Montfort.

"Les ennemis du comte de Toulouse obtiennent, malgré lintervention de l'archidiacre de Lyon, de l'archevêque de Narbonne et de l'abbé de Beaulieu, que la garde des terres soit confirmée à Simon de Montfort. Le comte Raimon et le comte de Foix viennent alors protester contre la sentence et prendre congé du Pape.

Celui-ci fait rendre son chateau au comte de Foix et retient auprès de lui le jeunne comte de Toulouse, auquel il assigne le Venaissin et le pays d'Argence; il promet de lui faire restituer plus tard, s'il mérite, tout l'heritage de son père" (39).

Se Filipe-Augusto não participou da Cruzada, permitiu, entretanto, que lá se fizesse tôda a sorte de devastações e usurpações, pois estava "persuadido que, de um vassalo despojado, sòmente a realeza podia ser, finalmente, a herdeira" (40).

Pelos Estatutos de Pamiers, consolidava-se a conquista e o Languedoc era submetido à dominação militar e sacerdotal. Simon de Montfort com a cruzada, conseguira o que não haviam conseguido os condes de Toulouse: a submissão da feudalidade do Languedoc.

Apesar da oposição, nem sempre clara do papa, Simon, no concílio de Montpelker (janeiro de 1215), foi eleito "príncípe e soberano do Languedoc". O príncipe Luiz apoiou-o e, para tan-

\footnotetext{
(38). - "La Chanson de la Croisade contre les Albigeois” - págs. 24, 25 e 26.

(39). - Idem obr. cit. - pags. 52 e 53 .

(40): - Joseph Calmette - "Le Monde Féodal" - Col. "Clio" - pág. 309.
} 
:o, esteve no Languedoc acompanhado pelo legado pontifical, $\mathrm{Pe}$ dro de Benevento. As cidades eram, entretanto, secretamente hostis a Montfort, mas abriram a porta aos representantes da Corôa e da Santa Sé.

Para contrabalançar o poderio de Simon de Montfort, o papa investiu o abade Arnaud Amalric no ducado de Narbonne.

Entretanto, Inocêncio III nada mais pôde fazer. Alegando o perigo do recrudescimento da heresia, recusavam-se os prelados do Midi a devolver os feudos aos seus antigos possuidores. Inocêncio foi obrigado, então, a reconhecer as conquistas e curvou-se às de cisões do Concílio de Latrão de 1215.

Depois do Concílio de Latrão, Raimundo foi permanentemente excluído da carreira pública. As decisões do Concílio não foram bem recebidas no condado de Toulouse e nem na Provença. As canções dos poetas trovadores trazem súplicas amargas e queixumes contra tal situação.

Afinal Montfort apoderava-se de tudo que desejava.

A aproximação entre Raimundo VI e João-sem-Terra inquietava Filipe-Augusto que, por isso, procurcu garantir a fidelidade de Simon de Montfort, enfeudando-lhe o condado de Toulouse. Restaram, pois, ao único filho de Raimundo VI, Nimes, Beaucaire e a Provença.

Mas foi efêmero o prestígio de Montfort. Toulouse recusouse a reconhecê-lo e revoltou-se contra êle. Em 13 de setembro de 1216, Raimundo VII recobrou Toulouse. Durante nove meses Montfort cercou a cidade. Afinal, durante o cêrco foi morto. Uma pedra de grande tamanho, atirada do alto da fortaleza, esmagouo em 25 de junho de 1218 . Diante da notícia da morte do tirano todo o Languedoc se insurgiu.

"Dans Toulouse entre un messager qui conte la nouvelle. Si grande est l'allégresse que, par toute la ville, les habitants courent aux églises où ils allument les cierges sur tous les chandeliers. Ils poussent des cris de joie et remercient de ce que Parage a recouvré sa splendeur et repris le dessus, tandis que le comte, cet homicide, cet homme sanguinaire, est mort sans absolution. Les cors, les trompes, les carillons, les volées et les sonneries des cloches, les tambours, les timbales et les petits clairon font retentir la ville et le pavé" (41).

Alarmado, o novo papa Honório III proclamou novamente a cruzada.

Coube o comando a Amaury de Montfort, filho de Simon de Montfort. O novo papa Honório III sabendo que Amaury não estava à altura de seu pai, ainda uma vez suplicou a Filipe-Augusto que dirigisse a cruzada. Novamente o rei recusou-se, pois preferia estar de sobreaviso contra as ambições de João-sem-Terra.

(41). - "La Chanson de la Croisade contre les Albigeois" - pág. 143. 
Por isso confiou o comando da cruzada ao conde Thibaud de Champagne.

Apesar do socôrro real enviado com o príncipe, a cruzada fracassou, pois Raimundo resistiu em Toulouse e expulsou Amaury de seus territórios. No início do reinado de Luiz VIII, Amaury foi expulso de Carcassonne, seu último refúgio. Diante do fracasso da cruzada, os "perfeitos" desceram das montanhas em que haviam se refugiado os poucos que restaram do tremendo massacre e reiniciaram as suas pregações...

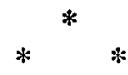

\section{A SEGUNDA CRUZADA REAL (1226)}

Em 1226, Honório III conseguiu superar as dificuldades políticas que se sobrepunham à conservação da fé no Sul da França. A Romano, cardeal de Santo Ângelo, coube coordenar os preparativos para a Cruzada. Raimundo foi excomungado e com a desistência do Senhor de Montfort, foi confiada a Luiz VIII a direção da cruzada, nos Concílios de Paris e de Bourges.

Bourges foi o centro em que se concentraram as tropas vindas de tôdas as partes do reino e onde vinham prestar homenagens ao rei. No Languedoc, os bispos foram incumbidos de receber a submissão dos senhores.

Em março de 1226 seguiu o exército real para o Sul, acompanhando a via tradicional: a margem esquerda do rio Ródano.

O objetivo da cruzada era Avinhão, onde o número de cataros era considerável. Temendo, provàvelmente, a pilhagem, a população fechou as portas e por isso a cidade foi cercada. Durante muito tempo Avinhão resistiu aos assaltos do exército real. Mas finalmente, ante tão grande poderio que a cerclava, a cidade capitulou. O legado sequestrou as terras da margem esquerda do Ródano que foram ocupadas em nome da Santa Sé.

O terrível desastre de Avinhão serviu de execração para o resto do Languedoc que, sem grande resistência, submeteu-se.

Aos que não se entregaram, Luiz VIII ameaçou com a morte na fogueira, mas é provável que esta cruzada de 1226 não tenha queimado heréticos.

A cruzada trouxe grandes proveitos para Luiz VIII que confiscou todos os bens dos heréticos em seu proveito. Na Assembléia de Pamiers (outubro de 1226) decidiu-se que todos os feudos ocupados pelos heréticos pertenciam ao rei de França. Assim, regularizavam-se as coisas em proveito da Igreja e do Rei.

Raimundo concordava em sujeitar-se como súdito leal e vassalo. Afinal, foi obrigado a submeter-se, pelo tratado de Meaux (1229) e a aceitar uma série de humilhações, tais como a demolição da maior parte dos muros de Toulouse; prometeu proteger o 
clero e os bens da Igreja, combater a heresia e receber a cruz das mãos do legado, ir à Palestina dentro de dois anos. Conservaria o condado de Toulouse, mas assegurava a sucessão à sua filha Joana, casada com Afonso, irmão do jovem rei Luiz IX (42).

Consentindo em tais condições, Raimundo teria sido levado pela convicção de que seria falta de visão política, continuar a guerra contra fôrças invenciveis. Prometendo sua ativa e incondicional cooperação no sentido de extirpar a heresia e, conseqüentemente, auxiliando as duas grandes ordens mendicantes, é provável que quisesse dar um senso de contrição às loucuras de seu pai que acabaram por arruinar a sua casa. A maneira pela qual Inocêncio III se compadeceu de sua infância desamparada, criou dentro do jovem conde uma verdadeira admiração pelo seu protetor e simpatia para com os seus desígnios (43).

Apesar da morte prematura de Luiz VIII, Raimundo não obteve a independência. A paz era necessária depois de tantas devastações. Para obtê-la, uniu-se aos perseguidores e expediu, de acôrdo com o rei e com o papa, ordenanças para a perseguição aos infiéis. Estas ordenanças marcam a introdução da Inquisição na França em 1223.

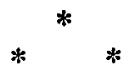

\section{A INQUISIÇÃO, O CATARISMO E O ESTADO}

"Numa sociedade em que a religião era fundamentalmente incorporada ao Estado, a heresia era olhada como contrária à ordem pública e todo o herético tratado como conspirador e traidor, podendo sofrer pena de morte" (44).

Tal concepção decorre da noção romana de govêrno em que se fundiam inteiramente a religião e o Estado. Fundamentando-se nesta concepção, a estrutura política medieval, lògicamente, sob um ponto de vista jurídico, a heresia albigense era considerada como ameaça às instituições essenciais do Estado. G. Ambroise reconhece que "a heresia albigense e a heresia valdense são tentativas de libertação política, manifestações de independência do Midi, mais que revoltas contra a autoridade eclesiástica" (45).

Em virtude da íntima ligação existente entre a Igreja e o Estado, e como a Igreja atribui a si a defesa das instituições e da paz social ameaçadas, instala-se no Languedoc, o tribunal da Inquisição, mais como um orgão com funções políticas e sociais do que como tribunal essencialmente religioso. A Inquisição foi, e sempre

(42). - Abbé A. Boulenger - "Histoire Générale de l'Eglise" - Tomo II - págs. 317 e 318.

(43). - Encyclopaedia of Religion and Ethics - pág. 286.

(44): - G. Ambroise - "Les moines du Moyen Âge" — págs. 159-160.

(45). - Idem, obr. cit. - pág. 161 . 
seria, um instrumento de opressão destinado a manter a ordem social e política estabelecida e a impedir uma profunda transformação social decorrente de uma luta de classes e de uma revolução econômica evidentes.

As primeiras medidas inquisitoriais datam do pontificado de Lúcio III, em 1184. Os bispos deveriam visitar duas vêzes por ano as localidades suspeitas; dois homens honrados, comprometidos por juramento deveriam auxiliar os bispos na denúncia dos suspeitos de heresia. No Languedoc, as medidas foram francamente ineficazes, uma vez que eram numerosíssimos os bispos e diáconos dissidentes.

Em 1204 Inocêncio III mudou o processo inquisitorial; a incumbência não cabia mais a bispos do Languedoc mas às ordens monásticas, estranhas a injunções sociais e políticas da região e, por natureza e votos, profundamente devotadas à causa pontifical. Recebiam o nome de legados e sua função deveria ser, em princípio, a evangelização dos herejes. Bispos e fiéis deveriam aprovar o trabalho dos legados. Em 1208 apareceram aí os monges de São Francisco de Assis e em 1215, os de São Domingos.

Até o assassinato do legado Pierre de Castelnau, os legados pontificais usaram apenas prccessos puramente espirituais, mas a violência chamou a violência e a Igreja passou a usar medidas de repressão e perseguição.

As primeiras regras gerais destinadas a regular o processo contra os infiéis datam do Quarto Concílio de Latrão de 1215. Outras medidas foram tomadas por Honório III, Gregório IX e pelo Concílio de Toulouse de 1229.

Estas regras gerais estabeleciam que os heréticos seriam punidos pelas autoridades civís. Caso um eciesiástico fôsse culpado de crime de heresia, deveria ser degradado primeiro, para depois ser julgado.

Quando não pudesse ser provada a heresia, então o suspeito seria excomungado e evitado por todos, pois a excomunhão recairia sôbre aquêles que com êle convivessem (46).

A legislação eclesiástica, porém, não previa a pena de morte, pois os grandes pensadores católicos mostravam-se profundamente escrupulosos quanto aos derramamentos de sangue e mortes violentas. As autoridades civis é que deveriam aplicar as penas próprias aos heréticos, contra os quais fôsse provada a heresia.

Frederico II interferiu enèrgicamente na Lombardia a pedido de Honório III, quando a heresia havia tomado aí grande vulto. Ficou estabelecido, então que, quando o bispo apresentasse provas conclusivas da heresia, a autoridade civil cortaria a língua do hereje, deixando-o vivo para a execração.

Este foi o primeiro passo para o estabelecimento de penas mais terriveis.

(46). - Gustave Scbnürer - obr. cit. - pág. 615. 
Provàvelmente já vinha sendo aplicada há muito tempo a pena de morte contra os herejes. Como já vimos, em 1199, Inocêncio III encontrou suas justificações no Direito Romano.

Foi a Gregório IX, porém, que coube a unificação das diversas formas de processo contra os heréticos.

A denúncia de heresia não caberia mais a simples delatores, mas a autoridades nomeadas pelo papa.

Foi a Conrado de Marburgo que o papa confiou, pela primeira vez, em 1227, auxiliado por companheiros, a missão de procurar herejes.

A fim de impedir a interferência da Igreja nos assuntos de seu reino, Frederico II desejou que a êle fôsse confiada a missão de perseguir heréticos no reino da Sicília.

Frederico II não visava, porém, interêsses religiosos, mas a êle importavam muito mais os fins políticos. Usando dêste meio, procurou investir contra inimigos do Império e, principalmente, nas cidades lombardas onde havia grande número de heréticos.

Gregório IX não podia confiar nos desígnios de Frederico II e por isso reconheceu apenas parcialmente os seus decretos. Assim, confiou oficialmente, em 1231, ao legado Conrado de Marburgo a função de inquisidor. Daí por diante esta missão passou a ser entregue a monges franciscanos e dominicanos.

Marburgo agiu com tanto furor, mostrou-se de tal maneira vingativo, que caiu vítima do ódio do povo.

Em 1233 foi introduzida a Inquisição na França. O inquisidor Ferrier destacou-se pelo zêlo fanático, tendo levado, com o apôio dos legados pontificais, inúmeros heréticos à fogueira.

Em fanatismo e zêlo, excedeu a Conrado de Marburgo e Ferrier, na França, o inquisidor dominicano, Robert. Tendo sido, anteriormente, cataro, era conhecido com o apelido de Robert, le Bougre. Em 1229 lançou à fogueira, em poucos dias, mais de 180 pessoas .

O processo inquisitorial para obrigar o herético a confessar a heresia e reconciliar-se com a Igreja, era crudelíssimo.

Reconhecida a heresia, seus bens eram imediatamente confiscados. Em seguida o réu de heresia era submetido a terríveis castigos. Se a lei estabelecia que o réu só podia ser castigado uma vez, os casuistas argumentavam que podia ser castigado uma vez com cada instrumento de suplício. Daí terem sido inventados muitos gêneros de suplícios. Levados a julgamento, os herejes eram julgados secretamente e não tinham direito à defesa. Eis a razão do horror que inspirava tal tribunal.

Se fôsse realmente constatada a heresia e se o réu se recusasse a abjurar, então era remetido ao braço secular que se incumbia de aplicar a pena. Assim a Igreja afastava de si, expressamente, a responsabilidade da pena de morte a que, teòricamente, condenava. 


\section{Schnürer assim justifica a Inquisição:}

"Se é impossivel justificar a Inquisição no seu conjunto, o historiador pode explicar fàcilmente a sua origem. A época em que ela nasce é aquela em que o cristianismo combatia o Islão por meio de guerras sangrentas nas quais lutava-se pelas armas no Norte e ao Sul, pela honra do cristianismo e da propagação da Igreja. Acalentavam-se esperanças exaltadas: esperava-se quando o Império latino se edificasse em Constantinopla, não sòmente a volta dos gregos à Igreja de Roma, mas também do Islão e a conversão da maior parte dos tártaros. Em tempo de guerra no seio da cristandade, heréticos eram semelhantes a traidores numa fortaleza assediada. Eis porque nenhuma das partes da Inquisição era, em principio, contestada. Todo o mundo aprovava a perseguição aos herejes. Sempre por meio de novas crueldades, pensava-se aumentar o horror ao crime e visto que cada vez mais estava em jôgo o interêsse da fé, aquêles que de outra maneira teriam hesitado, pensaram que a fé era uma coisa de tal modo preciosa que todos os meios deviam ser empregados, para salvaguardá-la" (47).

O que não se justifica, porém, são os excessos que praticou, nem o fato de ter sido largamente usada como instrumento político de muitos reis, em conivência com a própria Igreja.

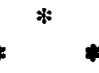

\section{CONCLUSÕES}

A heresia constituia, realmente, para a Igreja, uma ameaça aos seus dogmas; mas isto não ocorria pela primeira vez. O maniqueismo não era uma novidade. Em diversos pontos do Ocidente Cristão, desde a Antigüidade e nos primeiros séculos da Idade Média, ressurgiram heréticos maniqueus. Nem a humanidade estava ameaçada pela supressão do casamento, uma vez que a castidade era observada por uma infima minoria de "perfeitos".

A ameaça era séria, mas a Igreja poderia vencê-la com os seus próprio meios, como já havia suprimidos outros focos de maniqueus durante o século $\mathbf{X}$.

Agora, porém, o problema era realmente grave, não porque pudesse ocorrer, naquela ocasião, um cisma dentro da Igreja, mas porque o regime político e a ordem social haviam sido fundamentalmente ameaçados em virtude de transformações de ordem econômico-social, das quais a heresia é uma simples manifestação. Era uma verdadeira revolução sob o disfarce de uma insurreição religiosa.

Fermentava-se a política interna e externa do reino. Havia olhos cobiçosos voltados para o Languedoc. Estavam ameaçados os vastos domínios da Igreja no Sul da França; periclitava o poder de 
Filipe-Augusto e de seus sucessores sôbre importantes feudos do Languedoc. A Igreja precisava defender o seu sustentáculo, o mais importante dos principes cristãos do Ocidente, ainda que curvando muitas vêzes à sua vontade, uma vez que se sentia ainda desafiada pelos imperadores e pela ousadia de João-sem-Terra.

Assim, a função política tornou-se muito mais importante que a função religiosa da Cruzada. A defêsa da fé passava para um segundo plano; lutava-se para salvaguardar interêsses, bens, propriedades ou para usurpar, sob o pretexto de Cruzada, os restos do vencido.

Apenas os pobres e os humildes tinham uma fé a ser defendida, sua única esperança de dias melhores. Foram êles que sofreram as mais duras consequiências. O Languedoc foi devastado; os castelos, destruídos; as cidades, pilhadas; os campos incendiados; por tôda a parte, ruína, miséria e desolação. Eles é que sofreram realmente as conseqüências desta guerra terrível sem nada conseguir em seu proveito.

Sem ter interferido diretamente na Cruzada foi a realeza que gozou tôdas as vantagens. O rei submeteu súditos rebeldes, incorporou grandes e ricos domínios; não tendo participado do cêrco e saque das cidades, foi olhado com simpatia pelos burgueses que sentiram como inimigos, os barões do Norte e os bispos, não o rei da França, a quem reiteraram sua fidelidade. O próprio Raimundo VII reconhecia-se vassalo do Rei e reafirmava a sua fidelidade.

Houve uma transformação política necessária para o estabelecimento de uma ordem social em equilibrio com as transformações econômicas decorrentes do renascimento do comércio.

Fortaleceu-se a realeza com a aquisição de novos territórios e a submissão da feudalidade do Languedoc; contra os privilégios do senhores eclesiásticos ou leigos buscou o apôio da forte burguesia do Languedoc e para manter a sua fidelidade, a realeza procurou favorecer as manifestações contemporâneas ou posteriores da Revolução Comunal.

Com o estabelecimento da Inquisição, tribunal de terror e de opressão, a Igreja suprimiu novas manifestações subversivas da ordem social e religiosa, manteve a unidade da Igreja à custa da violência, suprimindo por quase dois séculos, todos os perigosos focos de heresia.

Prenunciava-se, porém, a tempestade ao século XVI...

MARIA HENRIQUETA FONSECA

Licenciada em Geografia tistória pela Faculdado de Filosofia, Ciências e Letras da Universidade de São Paulo. 


\section{BIBLIOGRAFIA UTILIZADA.}

Charles Petit-Dutaillis et P. Guinard: —. "L'Essor des Etats d'Occident" - Collection d'Histoire Générale (Gustave Glotz). Tomo IV. Presses Universitaires de France. Paris, 1944..

Emmanuel Aegerter: - "Les héresies du. Moyen Ãge" - Librarie Ernest Léroux. Paris, 1939.

Encyclopaedia of Religion and Ethics: - Edited by James Hastings M. A., D. D. Vol. I. Edimburgo, 1908.

Gustave Schnürer: - "L’Église et la civilisation au Moyen Âge". Payot. Paris, 1935.

Kenneth Scott Latourette: - "The thousand year of uncertanity. A History of Christianity". Vol. II. Harper \& Brother. Londres e Nova York.

John D. Davis: - "Dicionário da Bíblia". Imprensa Metodista, 1928.

M. Koch: - "Révolutions de l'Europe". Librarie de Gide Fils. Paris, 1823.

Augustus Neander: - "General History of Christian Religion and Church" translated from the German by Joseph Torrey. Vol. VIIII. Londres, 1867.

Rev. Handley C. G. Moule, DD.: - "Exposición de la Epístola de San Pablo a los Romanos". Editôra "La Reforma". Argentina, 1924 .

Augustus Hopkins Strong, DD., LL. D.: - "Systematic Theology". Vol. II. "The doctrine of man". Judson Press. Filadélfia.

Samuel M. Zwemwer: - "The origin of religion". Cap. IV. Cokesbury Press. Nashville, Tennessee.

Ernest Lavisse: - "Histoire de France - Des Origines à la Révolu' tion". Tomo III - 1..$^{\mathrm{a}}$ parte. Librarie Hachette.

Enciclopedia Católica: - Città del Vaticano.

Abbé A. Boulenger: - "Histoire Générale de l'Église”. Tomo II "Le Moyen Ãge", Tomo V - "De Gregoire Vir a Clément V" - 1073-1305. Librarie Catholique Emmanuel Vite, 1935.

Albert Dufourcq: - "Histoire Moderne de l'Église". Tomo VI — "Le Christianisme et l'organisation féodale", (1049-1294).

Altamira y Crevea: - "Historia da España y de la civilización española". Vol. I. Barcelona, 1929.

Don Modesto Lafuente: - "Historia de España. Tomo III (976-1217). Barcelona, 1922.

Georgene W. Davis: - (Register and Analysis) "The Inquisition at Albi - 1299-1300". New York Columbia University Press, 1948. 
Pierre Belperron: - "La Croisade contre les Albigeois et l'union du Languedoc a la France - 1209-1243". Librarie Plon. Paris.

Henri Pirenne: - "Histoire de l'Europe - Des invasions au XVIe. siècle". Éditions de la Baconnière. Neuchâtel.

Augustin Fliche et Victor Martin: - "Histoire de l'Eglise (depuis ses origines jusqu'à nos jours) - Vol. IX - Du premier Concile de Latran à l'avénement d'Innocent III - 1123-1198, par Augustin Fliche, Raymonde Foreville et Jean Rousset. Bloud et Gay. Paris.

"La Chanson de la Croisade contre les Albigeois": - "Poèmes et recits de la vieille France". E. de Boccard. Paris, 1924.

André Gourdin: - "Langue et Literature d'Oc" - Col. "Que sais-je?" Presses Universitaires de France. Paris.

R. Bousquet et V. L. Bourrilly: - "Histoire de la Provence"-Col. "Que sais-je?" - Presses Universitaires de France. Paris.

G. Ambroise: - "Les Moines du Moyen Âge" - (Leur influence intelectuelle et politique en France). A. Picard. Paris, 1946.

Dom Charles Poulet: - "Histoire du Christianisme" (Moyen Âge)" - Gabriel Beauchesne et ses Fils. Paris, 1934.

M. Jourdan: - "Les Institutions Eclesiastiques au Moyen Äge". Centre de Documentation Universitaire (incompleto). Paris.

Joseph Calmette: - "Le Monde Fiéodal" - Col. "Clio" - Presses Universitaires de France. Paris.

Jean Guirand: - "Saint Dominique" - (1170-1221). Librairie Lecoffre. Paris, 1934.

M. Deaniau: - "Les Ordres Réligieux en Occident du VIe. au XIVe. siècles". Les Cours de l'Université de Lyon.

"Biblia Sagrada" - Edição da Sociedade Bíblica Britânica. 